OPEN ACCESS

Edited by:

Atsushi Masamune,

Tohoku University, Japan

Reviewed by:

Shin Hamada,

Tohoku University, Japan

Hajime Isomoto,

Tottori University, Japan

${ }^{*}$ Correspondence:

Rui Xie

xr19841029@aliyun.com

Jingyu Xu

xujingyu_gzzy@126.com orcid.org/0000-0002-0545-0444

'These authors have contributed equally to this work

Specialty section:

This article was submitted to Gastrointestinal Sciences, a section of the journal Frontiers in Physiology

Received: 22 September 2021 Accepted: 01 December 2021 Published: 24 December 2021

Citation:

An Q, Yue G, Yang X, Lou J, Shan W, Ding J, Jin Z, Hu Y, Du Q, Liao Q, $X i e R$ and $X u J ~(2021)$ Pathophysiological Role of Purinergic P2X Receptors in Digestive System

Diseases.

Front. Physiol. 12:781069 doi: 10.3389/fphys.2021.781069

\section{Pathophysiological Role of Purinergic P2X Receptors in Digestive System Diseases}

\author{
Qimin An ${ }^{1,2 \dagger}$, Gengyu Yue ${ }^{1,2 \dagger}$, Xiaoxu Yang ${ }^{1,2}$, Jun Lou ${ }^{1,2}$, Weixi Shan ${ }^{1,2}$, Jianhong Ding ${ }^{1,2}$, \\ Zhe Jin ${ }^{1,2}$, Yanxia Hu ${ }^{1,2}$, Qian Du ${ }^{1,2}$, Qiushi Liao ${ }^{1,2}$, Rui Xie ${ }^{1,2 *}$ and Jingyu $X u^{1,2 *}$ \\ 'Department of Gastroenterology, Affiliated Hospital of Zunyi Medical University, Zunyi, China, ${ }^{2}$ The Collaborative Innovation \\ Center of Tissue Damage Repair and Regeneration Medicine of Zunyi Medical University, Zunyi, China
}

P2X receptors (P2XRs) are trimeric, non-selective cation channels activated by extracellular ATP and widely distributed in the digestive system. P2XRs have an important role in the physiological function of the digestive system, such as neurotransmission, ion transports, proliferation and apoptosis, muscle contraction, and relaxation. P2XRs can be involved in pain mechanisms both centrally and in the periphery and confirmed the association of P2XRs with visceral pain. In the periphery, ATP can be released as a result of tissue injury, visceral distension, or sympathetic activation and can excite nociceptive primary afferents by acting at homomeric P2X(3)R or heteromeric P2X(2/3)R. Thus, peripheral P2XRs, and homomeric $\mathrm{P} 2 \mathrm{X}(3)$ and/or heteromeric $\mathrm{P} 2 \mathrm{X}(2 / 3) \mathrm{R}$ in particular, constitute attractive targets for analgesic drugs. Recently studies have shown that P2XRs have made significant advances in inflammation and cancer. P2X7R mediates NLRP3 inflammasome activation, cytokine and chemokine release, T lymphocyte survival and differentiation, transcription factor activation, and cell death. The P2X7R is a potent stimulant of inflammation and immunity and a promoter of cancer cell growth. This makes P2X7R an appealing target for anti-inflammatory and anti-cancer therapy. It is believed that with the further study of P2XRs and its subtypes, P2XRs and its specific antagonists will be expected to be widely used in the treatment of human digestive diseases in the future.

Keywords: P2X receptors, extracellular ATP, physiological functions, digestive system diseases, inflammation, tumor

\section{INTRODUCTION}

Purine signal was first discovered in 1972 (Burnstock, 1972). It was not until 1976 that Burnstock and his team first proposed the concept of purine receptor (Burnstock, 1976). Purine receptors can be divided into P1 receptors whose main ligands are adenosine and $\mathrm{P} 2$ receptors whose main ligands are nucleotides according to their ligand types. P2 receptors (P2Rs) fall into two classes, the ionotropic P2X receptors (P2XRs) and the metabotropic P2YRs (Burnstock, 2018). P2XRs are cell membrane cation channels that are gated by extracellular ATP, and the ATP-mediated opening of these channels allows $\mathrm{Ca} 2+$ and $\mathrm{Na}+$ influx, as well as $\mathrm{K}+$ efflux. Seven subtypes of P2X receptors have been cloned and denoted as $\mathrm{P} 2 \mathrm{X} 1$ to $\mathrm{P} 2 \mathrm{X} 7$, and in three heteromeric receptors identified as $\mathrm{P} 2 \mathrm{X} 2 / 3, \mathrm{P} 2 \mathrm{X} 4 / 6$, and 
P2X1/5, with functional channels assembled by homo- or heterotrimers (Saul et al., 2013). In 2012, Hattori et al. reported the open crystal structure of the zfP2X4 receptor with ATP in its binding site, which confirmed previous studies on ATP recognition and provided structural insight into the channel gating of P2X receptors (Hattori and Gouaux, 2012). Their research showed that All subtypes share a common topology containing two transmembrane domains (TM1and TM2), a large Cys-rich extracellular domain ( 280 residues) and intracellular C- and N-termini. Because the overall structure of each receptor subunit resembles the shape of a "leaping dolphin," thus different domains of P2X are named as head, dorsal fin (DF), left flipper (LF), right flipper (RF), body, and fluke. The TM helices (TM1 and TM2) of a single subunit delineate the "fluke" of the "dolphin" and are involved in many properties of $\mathrm{P} 2 \mathrm{X}$ receptors, including unitary conductance and rectification, differential desensitization among subtypes, and voltage-dependence of P2X receptors. The extracellular domain delineate the "head" and "LF" or "DF" and "upper body domains" of "dolphin" harbors binding sites for ATP, competitive antagonists, and modulatory metal ions. The $\mathrm{N}$-terminus is composed of approximately 30 amino acid residues, while the C-terminus comprises approximately 30-240 amino acid residues, varying among different subtypes (Hattori and Gouaux, 2012; Jiang et al., 2012, 2013; Habermacher et al., 2016; Wang and Yu, 2016). Therefore, these structural characteristics of $\mathrm{P} 2 \mathrm{X}$ determine the gating process of $\mathrm{P} 2 \mathrm{X}$ receptors. Following ATP binding, the head domain moves downward, the DF domain moves upward and the LF domain is pushed away from the binding site. Because of the coupling between the LF, DF, and lower body domains, the relative motions of the LF and DF are capable of driving the outward expansion of the lower body, followed by the movements of TMs and subsequent opening of the ion access route. In conclusion, the gating process consists of a series of complicated and coordinated motions of multiple domains, which leads to the final channel opening of P2X receptors (Wang and $Y u, 2016)$. This conformational change makes the channel highly permeable to $\mathrm{Na}^{+}, \mathrm{K}^{+}$, and $\mathrm{Ca}^{2+}$, which triggers rapid membrane depolarization (Hattori and Gouaux, 2012; Kawate, 2017). A large number of studies have found that P2XR(s) are widely expressed in excitatory and non-excitatory cells, such as neuron, glia, platelet, epithelia, and macrophage (Figure 1), and participate in a series of important physiological and pathological processes, including the regulation of synaptic transmission, smooth muscle contraction, pain perception, inflammation, cardiovascular modulation, immunomodulation, and tumorigenesis. In this review, we mainly emphasize the important role of $\mathrm{P} 2 \mathrm{XR}(\mathrm{s})$ in the physiology and pathology of the esophagus, stomach, liver, pancreas, and colon (Table 1).

Abbreviations: R, receptor; BzATP, dibenzoyl-ATP; TM, transmembrane; DRG, dorsal root ganglia; $\alpha, \beta$-meATP, $\alpha, \beta$-methylene ATP; NG, nodular ganglion; IGLEs, Intraganglionic laminar endings; APAP, acetaminophen; A-438079, P2X7 receptor antagonist; AP, acute pancreatitis; $\mathrm{BBG}, \mathrm{P} 2 \mathrm{X} 7$ receptor antagonist brilliant blue; TAA, thioacetamide; PSC, pancreatic stellate cells.

\section{ESOPHAGUS}

In the past, it has been found that $\mathrm{P} 2 \mathrm{XR}(\mathrm{s})$ are expressed and distributed in the esophagus, such as esophageal vagal afferent neurons and esophageal smooth muscle cells, and play an important role in the physiology and pathology of the esophagus. Intraganglionic laminar endings (IGLEs) are the transduction sites of the mechanical receptors of the vagus nerve in the esophageal muscle layer. It has been found that $\mathrm{P} 2 \mathrm{X} 2 \mathrm{R}, \mathrm{P} 2 \mathrm{X} 3 \mathrm{R}$, and isomeric $\mathrm{P} 2 \mathrm{X} 2 / 3 \mathrm{R}$ are expressed on the IGLEs in rats, mice, and guinea pigs, and the number of receptors in the ventral segment of the esophagus increases as they travel to the esophagus. Therefore, $\mathrm{P} 2 \mathrm{XR}(\mathrm{s})$ may be an important regulator of the mechanical sensory characteristics of the esophageal vagus nerve (Castelucci et al., 2003; Wang and Neuhuber, 2003; Zagorodnyuk et al., 2003; Kestler et al., 2009). In addition, P2XR(s) are also expressed in the esophageal sphincter and smooth muscle. P2XR(s) can stimulate excitatory motor neurons on the esophageal sphincter to induce esophageal sphincter contraction in porcine lower esophageal sphincter (LOS; Lecea et al., 2009). In cat esophageal smooth muscle, $\alpha$, $\beta$-metATP acts on $\operatorname{P} 2 \mathrm{XR}(\mathrm{s})$ in a concentration-dependent manner to induce voltage-gated $\mathrm{Ca}^{2+}$ channel sensitive to dihydropyridine, so as to mediate $\mathrm{Ca}^{2+}$ influx and enhance EFS-induced contraction of esophageal smooth muscle induced by electric field (Cho et al., 2010) (Figure 2).

\section{P2X Receptors and Esophageal Pathology}

Studies have shown that P2X3R is mainly expressed in nociceptive sensory neurons and plays a key role in nociceptive signaling (Wirkner et al., 2007). It has been documented that visceral afferent fibers undergo sensitization following visceral inflammation. For example, vagal mechanosensitive afferents innervating the esophagus of ferrets exhibit significantly greater response to $\mathrm{P} 2 \mathrm{X} 3$ receptor agonist $\alpha, \beta$-methylene ATP following esophagitis (Page et al., 2000). In 2009, Banerjee and his team found that in rats with a model of esophagitis, the expression of $\mathrm{P}_{2} \mathrm{X}_{3} \mathrm{R}$ was significantly upregulated in the vagus nerve and spinal afferent nerve, which may be related to the enhancement of esophageal hypersensitivity caused by esophagitis (Banerjee et al., 2009). Moreover, $\mathrm{P} 2 \mathrm{XR}(\mathrm{s})$ indirectly enhances esophageal hypersensitivity by inducing changes in afferent nerve function, which is related to non-erosive reflux disease (NERD; Page et al., 2000; Miwa et al., 2010). Therefore, ATP and P2X3 ion channel receptor antagonists may be potential targets for the treatment of esophageal hypersensitivity (Table 2). In recent years, $\mathrm{P} 2 \mathrm{X} 3$ receptor antagonists have been reported, such as A-317491, Diaminopyrimidines, AZ004 (Jarvis et al., 2002; Gever et al., 2010; Ballini et al., 2011; Ford, 2012).

\section{STOMACH}

It has been found that $\operatorname{P2XR}(s)$ are expressed in different parts of the stomach, such as Gastric smooth muscle cells, 


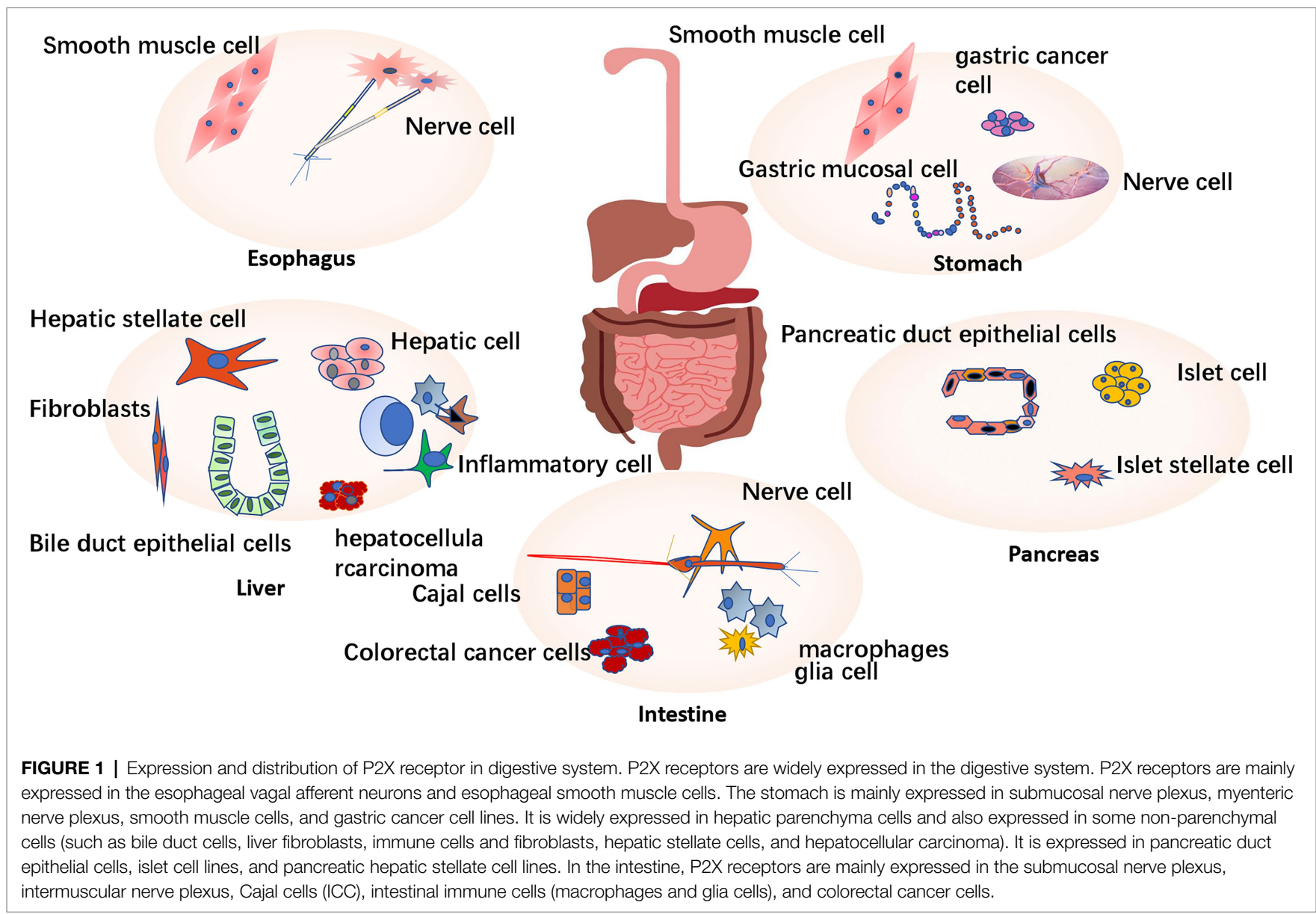

nodose ganglion cells, gastric vagal afferent nerve cells, gastric epithelial cells and gastric cancer cell lines, regulating gastric smooth muscle contraction, relaxation, nociceptive visceral sensory afferent, gastric acid secretion and invasion, and metastasis of gastric cancer. There are some differences on the role of $\mathrm{P} 2 \mathrm{XR}(\mathrm{s})$ in regulating the contraction or relaxation of gastric smooth muscle, the earliest studies have found that $\mathrm{P} 2 \mathrm{XR}(\mathrm{s})$ are involved in mediating gastric smooth muscle relaxation in rat and guinea pig gastric smooth muscle (Lefebvre and Burnstock, 1990; Matharu and Hollingsworth, 1992; Ahn et al., 1995). However, later studies have shown that $\mathrm{P} 2 \mathrm{XR}(\mathrm{s})$ mediate gastric smooth muscle contraction. In 2005, Mule and his team confirmed that $\mathrm{P} 2 \mathrm{XR}(\mathrm{s})$ are expressed on gastric excitatory neurons in mice, and gastric smooth muscle contraction is mediated by activation of ATP and $\alpha, \beta$-meATP (Mule et al., 2005). The nodose ganglion (NG) is the main parasympathetic ganglion conveying sensory signals to the CNS from numerous visceral organs including digestive signals, such as gastric distension or the release the gastrointestinal peptides. The primary viscerosensory afferents of the vagus are comprised of a combination of unmyelinated C-type and lightly myelinated A $\delta$-type axons, and the cell bodies for these afferents reside in the nodose ganglion (NG; Gebhart and Bielefeldt, 2016). Vagal afferents relay stimuli from multiple visceral tissues including the heart, lungs, vasculature, gastrointestinal (GI) tract, and the accessory organs necessary for digestion. These primary visceral afferents must respond to organ specific stimuli in order to generate appropriate efferent responses. For example, vagal afferents innervating gastrointestinal (GI) tract chemical and mechanical stimuli to the brainstem as part of the parasympathetic control of nutrient homeostasis (Kentish and Page, 2015). ATP is a major diffusible signaling molecule that is released by neurons, glia, and immune cells, and is responsible for the proper control of GI functions and sensory afferents (Burnstock, 2016a). In addition, P2XR(s) expressed in the sensory afferent nerves and epithelial cells of the stomach can act as indirect acid receptors by increasing ATP release and activating $\mathrm{P} 2 \mathrm{XR}(\mathrm{s})$ when extracellular $\mathrm{pH}$ is decreased, causing proton currents, thereby regulating gastric acid secretion (Holzer, 2011).

\section{P2X Receptors and Visceral Nerve Sensory Transmission}

Blanke and his team confirmed that $\mathrm{P} 2 \mathrm{X} 3 \mathrm{R}$ is expressed in $\mathrm{NG}$ neurons and is sensitized following $\mathrm{Ca}^{2+}$ entry, thus causing neuroplastic changes within the NG neurons (Blanke et al., 2019). It has been found that when knockout of P2X3R gene slows the expansion of gastric vagal afferent nerve to stomach, 
TABLE 1 | Expression and distribution of P2X receptor in digestive organs and its biological effect with diseases of digestive system.

\begin{tabular}{|c|c|c|c|c|c|}
\hline Organs & P2XR subtypes & Target cells & Related diseases & Biological effect & References \\
\hline Esophagus & P2X3R & $\begin{array}{l}\text { Esophagus vagal } \\
\text { primary afferent } \\
\text { neurons }\end{array}$ & $\begin{array}{l}\text { Esophagus } \\
\text { hypersensitivity }\end{array}$ & $\begin{array}{l}\text { P2X3R promotes esophagus } \\
\text { hypersensitivity by indirectly enhancing } \\
\text { afferent nerve mechanical sensitivity }\end{array}$ & $\begin{array}{l}\text { Page et al., 2000; Banerjee } \\
\text { et al., 2009; Miwa et al., } 2010\end{array}$ \\
\hline \multirow[t]{2}{*}{ Stomach } & $\mathrm{P} 2 \times 3 \mathrm{R}$ & $\begin{array}{l}\text { Nodose ganglion } \\
\text { neurons }\end{array}$ & $\begin{array}{l}\text { Dyspepsia } \\
\text { hyperalgesia in gastric }\end{array}$ & $\begin{array}{l}\text { Indirectly enhances signal transduction in } \\
\text { the spinal cord and promotes dyspepsia } \\
\text { and hyperalgesia in gastric }\end{array}$ & $\begin{array}{l}\text { Dang et al., 2005; Blanke et al., } \\
2019\end{array}$ \\
\hline & P2X7R & Gastric cancer cells & Gastric cancer & $\begin{array}{l}\text { Enhances the proliferation, migration and } \\
\text { invasion of gastric cancer cells, via } \\
\text { modulating ERK } 1 / 2 \text { and Akt pathways and } \\
\text { EMT }\end{array}$ & $\begin{array}{l}\text { Lili et al., 2019; Calik et al., } \\
2020\end{array}$ \\
\hline \multirow[t]{7}{*}{ Liver } & $\begin{array}{l}\text { P2X1R, P2X4R, } \\
\text { P2X7R }\end{array}$ & $\begin{array}{l}\text { Peripheral blood } \\
\text { mononuclear cells } \\
\text { (PBMC) }\end{array}$ & Viral hepatitis & $\begin{array}{l}\text { Promotes PBMC-mediated immune } \\
\text { response in chronic HCV infection }\end{array}$ & $\begin{array}{l}\text { Manzoor et al., 2011, 2016; } \\
\text { Ashraf et al., } 2013\end{array}$ \\
\hline & P2X7R & $\begin{array}{l}\text { Hepatocytes and } \\
\text { macrophages }\end{array}$ & $\begin{array}{l}\text { Alcohol-associated } \\
\text { hepatitis }\end{array}$ & $\begin{array}{l}\text { ATP-induced P2RX7 signaling and NLRP3 } \\
\text { inflammasome produce IL-1 } \beta \text { accelerated } \\
\text { lipid accumulation in hepatocytes }\end{array}$ & $\begin{array}{l}\text { Iracheta-Vellve et al., 2015; Li } \\
\text { et al., 2018a,b; Freire et al., } \\
2019\end{array}$ \\
\hline & P2X7R & Hepatocytes & $\begin{array}{l}\text { Drug-induced liver } \\
\text { injury }\end{array}$ & $\begin{array}{l}\mathrm{P} 2 \mathrm{XR}(\mathrm{s}) \text { ion channel opens a large number } \\
\text { of } \mathrm{Ca}^{2+} \text { influx. The balance of intracellular } \\
\mathrm{Ca}^{2+} \text { is disrupted, which aggravated the } \\
\text { liver injury }\end{array}$ & $\begin{array}{l}\text { Hoque et al., 2012; Amaral } \\
\text { et al., 2013; Xie et al., } 2013\end{array}$ \\
\hline & P2X7R & NKT cells & Autoimmune hepatitis & $\begin{array}{l}\text { Activate or inhibit NKT cells to inhibit or } \\
\text { promote autoimmune hepatitis }\end{array}$ & $\begin{array}{l}\text { Kawamura et al., 2006; Beldi } \\
\text { et al., } 2008\end{array}$ \\
\hline & $\mathrm{P} 2 \times 4 \mathrm{R}, \mathrm{P} 2 \times 7 \mathrm{R}$ & $\begin{array}{l}\text { Kupffer cells, hepatic } \\
\text { stellate cell }\end{array}$ & Liver fibrosis & $\begin{array}{l}\text { Promote liver stellate cell activation, } \\
\text { proliferation }\end{array}$ & $\begin{array}{l}\text { LeRoy et al., 1990; Bataller and } \\
\text { Brenner, 2005; Ferrari et al., } \\
\text { 2006; Kawamura et al., 2006; } \\
\text { Mariathasan and Monack, } \\
\text { 2007; Rubartelli and Lotze, } \\
\text { 2007; Bieghs and Trautwein, } \\
\text { 2013; Huang et al., 2014; } \\
\text { Gentile et al., 2015; Robert } \\
\text { et al., 2016; Jiang et al., } 2017\end{array}$ \\
\hline & $\mathrm{P} 2 \times 4 \mathrm{R}, \mathrm{P} 2 \mathrm{X} 7 \mathrm{R}$ & Macrophages & Sepsis & $\begin{array}{l}\text { P2X7R signaling on myeloid cells } \\
\text { augments intracellular killing of bacteria in } \\
\text { sepsis. P2X4R augment bacterial killing } \\
\text { and protect against sepsis }\end{array}$ & $\begin{array}{l}\text { Gu et al., 2000; Savio et al., } \\
\text { 2017; Csóka et al., 2018; } \\
\text { Larrouyet-Sarto et al., } 2020\end{array}$ \\
\hline & $\mathrm{P} 2 \mathrm{X} 4 \mathrm{R}, \mathrm{P} 2 \mathrm{X} 7 \mathrm{R}$ & $\begin{array}{l}\text { Hepatocellular } \\
\text { carcinoma cell }\end{array}$ & Liver cancer & $\begin{array}{l}\text { Activate inflammasome, oxidative stress } \\
\text { and immune regulation, promote tumor cell } \\
\text { proliferation }\end{array}$ & $\begin{array}{l}\text { Nakanishi et al., 2005; Ghalali } \\
\text { et al., } 2017\end{array}$ \\
\hline \multirow[t]{5}{*}{ Pancreas } & P2X7R & Pancreatic cells & Acute pancreatitis & $\begin{array}{l}\text { P2X7R antagonist AME } 439079 \text { can } \\
\text { reduce the pancreatic edema and } \\
\text { significantly reduce pancreatic leukocyte } \\
\text { infiltration }\end{array}$ & $\begin{array}{l}\text { Hoque et al., 2011; Zhang } \\
\text { et al., } 2019\end{array}$ \\
\hline & P2X7R & Pancreatic stellate cells & Chronic pancreatitis & $\begin{array}{l}\text { Regulates the activation, proliferation and } \\
\text { apoptosis of pancreatic stellate cells }\end{array}$ & $\begin{array}{l}\text { Künzli et al., 2008; Haanes } \\
\text { et al., 2012; Wang et al., } 2015\end{array}$ \\
\hline & P2X3R & DRG neurons & & $\begin{array}{l}\text { Pancreatic hyperalgesia in chronic } \\
\text { pancreatitis }\end{array}$ & \\
\hline & P2X7R & Islet $\beta$ cells & Diabetes & $\begin{array}{l}\text { Mediating insulin secretion, survival and } \\
\text { apoptosis of islet } \beta \text { cells }\end{array}$ & $\begin{array}{l}\text { Coutinho-Silva et al., 2003; } \\
\text { Vieira et al., } 2016\end{array}$ \\
\hline & P2X7R & $\begin{array}{l}\text { Pancreatic ductal } \\
\text { adenocarcinoma cell } \\
\text { line }\end{array}$ & Pancreatic carcinoma & $\begin{array}{l}\text { Regulates the survival, migration and } \\
\text { invasion of pancreatic ductal } \\
\text { adenocarcinoma cell }\end{array}$ & $\begin{array}{l}\text { Mistafa and Stenius, 2009; } \\
\text { Mohammed et al., 2012; } \\
\text { Rodrigues et al., 2014; } \\
\text { Giannuzzo et al., } 2016\end{array}$ \\
\hline \multirow[t]{3}{*}{ Colon } & $\begin{array}{l}\mathrm{P} 2 \times 2 \mathrm{R}, \mathrm{P} 2 \times 3 \mathrm{R} \\
\mathrm{P} 2 \times 5 \mathrm{R}, \mathrm{P} 2 \mathrm{X} 6 \mathrm{R}\end{array}$ & $\begin{array}{l}\text { Colonic afferent nerve } \\
\text { endings, Colon-specific } \\
\text { dorsal root ganglion }\end{array}$ & $\begin{array}{l}\text { Irritable bowel } \\
\text { syndrome }\end{array}$ & $\begin{array}{l}\text { Mediates mechanical sensory transduction } \\
\text { such as visceral pain and promotes } \\
\text { hypersensitivity }\end{array}$ & $\begin{array}{l}\text { Wynn et al., 2003; Xu et al., } \\
\text { 2008; Shinoda et al., 2009; Hu } \\
\text { et al., 2017; Lashermes et al., } \\
2018\end{array}$ \\
\hline & $\begin{array}{l}\text { P2X4R, P2X4R, } \\
\text { P2X7R }\end{array}$ & $\begin{array}{l}\text { Intestinal immune cells } \\
\text { (macrophages and T } \\
\text { helper cells), Myenteric } \\
\text { plexus }\end{array}$ & $\begin{array}{l}\text { Inflammatory bowel } \\
\text { disease }\end{array}$ & $\begin{array}{l}\text { Promotes immune, inflammatory response, } \\
\text { in dyskinesia and pain }\end{array}$ & $\begin{array}{l}\text { Yiangou et al., 2001; Wynn } \\
\text { et al., 2004; Volonté and } \\
\text { Burnstock, 2013; Deiteren } \\
\text { et al., 2015; Hofman et al., } \\
2015\end{array}$ \\
\hline & P2X7R & $\begin{array}{l}\text { Colorectal Cancer cells } \\
\text { (HCT8 and Caco-2) }\end{array}$ & Intestinal cancer & $\begin{array}{l}\text { Promotes the invasion and migration of } \\
\text { colon cancer }\end{array}$ & $\begin{array}{l}\text { Coutinho-Silva et al., 2005; } \\
\text { Qian et al., 2017; Zhang et al., } \\
2020\end{array}$ \\
\hline
\end{tabular}




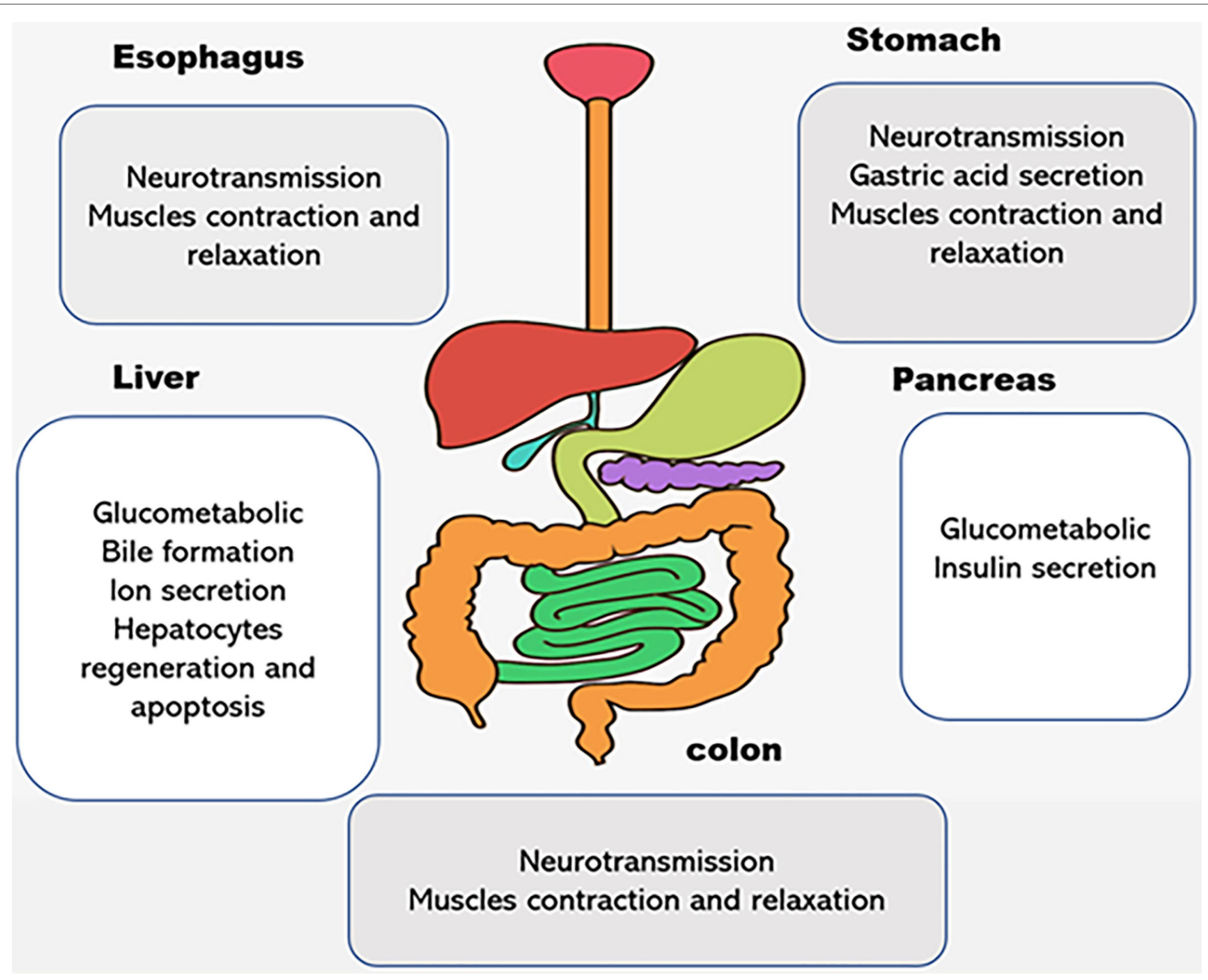

FIGURE 2 | The physiological functions of P2X receptors in digestive system. Different subtypes of P2X receptors are expressed in human esophagus, stomach, liver, pancreas, and colon. They play different roles in the regulation of physiological processes, such as neurotransmission, ion transports, proliferation and apoptosis, muscle contraction, and relaxation in the digestive organs.

TABLE 2 | Role of agonists and antagonists of the P2X receptors in digestive diseases.

\begin{tabular}{|c|c|c|c|c|}
\hline P2XR & Regulator & & Pharmacological function & References \\
\hline \multirow[t]{7}{*}{ P2X3R } & Agonists & $\alpha, \beta$-methylene-ATP & Promote esophageal hypersensitivity & Page et al., 2000 \\
\hline & & & Promotes gastric hypersensitivity & $\begin{array}{l}\text { Kentish and Page, 2015; } \\
\text { Burnstock, 2016a }\end{array}$ \\
\hline & & & Promotes intestinal hypersensitivity & Giaroni et al., 2002 \\
\hline & Antagonists & A-317491 & Blocks specifically P2X3R inhibition gastrointestinal tract hypersensitivity & Jarvis et al., 2002 \\
\hline & & AZOO04 & & Gever et al., 2010 \\
\hline & & Diaminopyrimidines & & Ballini et al., 2011 \\
\hline & & AF-353 & & Ford, 2012 \\
\hline \multirow[t]{3}{*}{$\mathrm{P} 2 \mathrm{X} 4 \mathrm{R}$} & Agonists & e-ATP & Sustain hepatic myofibroblasts activated and fibrogenic phenotype & Huang et al., 2014 \\
\hline & & Ivermectin & Against bacterial dissemination and mortality in sepsis & Benjamim et al., 2004 \\
\hline & Antagonists & & - & - \\
\hline \multirow[t]{7}{*}{ P2X7R } & Agonists & e-ATP & Contribute to the symptoms of IBD, including motor abnormalities, & Lashermes et al., 2018 \\
\hline & & BzATP & diarrheal state, and visceral pain & \\
\hline & Antagonists & A804598 & $\begin{array}{l}\text { Inhibits liver inflammation caused by combined chronic alcohol and } \\
\text { high-fat diet }\end{array}$ & Ashraf et al., 2013 \\
\hline & & A-438079 & Promotes liver injury in acetaminophen hepatotoxicity & Li et al., 2018b \\
\hline & & A438079, BBG & Inhibits liver fibrosis & $\begin{array}{l}\text { Mariathasan and Monack, } \\
\text { 2007; Gentile et al., } 2015\end{array}$ \\
\hline & & A-439079 & $\begin{array}{l}\text { Reduce the pancreatic edema and significantly reduce pancreatic } \\
\text { leukocyte infiltration, limit the Progression of pancreatitis }\end{array}$ & Burnstock, 2014 \\
\hline & & AZ10606120 & Inhibit the proliferation of pancreatic ductal adenocarcinoma & Novak et al., 2010 \\
\hline
\end{tabular}

considering the role of vagus nerve in the afferent signals of satiety and nausea, P2XR knockout may lead to the occurrence and development of dyspepsia. Therefore, P2X3R agonist may be a therapeutic target for gastrointestinal dyspepsia (McIlwrath et al., 2009). Dang and colleagues demonstrated this in a rat model of gastric ulcers, gastric sensory afferent neurons are 
overexcited and enhanced P2XR(s) activation, indirectly enhance signal transduction in the spinal cord, mediate gastric hypersensitivity, and promoted hyperalgesia in gastric ulcer under the influence of nociceptive stimuli, such as inflammation (Dang et al., 2005).

\section{P2X Receptors and Gastric Cancer}

In recent years, some studies have found that P2X7R also plays an important role in the development and prognosis of gastric cancer. Lili and his team confirmed that P2X7R is overexpressed in gastric cancer cell lines and tissues, and is related to several malignant characteristics of gastric cancer, such as promoting the proliferation, migration, and invasion of gastric cancer cells by regulating ERK1/2, Akt pathway, and EMT. Therefore, P2X7R can be used as a biomarker of gastric cancer, which is helpful to the prognosis of gastric cancer (Lili et al., 2019; Calik et al., 2020).

\section{LIVER}

$\mathrm{P} 2 \mathrm{X}$ receptors are widely expressed in the liver, including P2X1 P2X7 subtypes, P2X1R, P2X2R, P2X3R, P2X4R, and $\mathrm{P} 2 \mathrm{X} 7 \mathrm{R}$ are expressed in hepatocytes and Non-parenchymal cells, including hepatocytes, Kupffer cells, bile duct cells, hepatic stellate cell, hepatic fibroblasts, hepatocellular adenocarcinoma, and hepatocellular carcinoma (Fausther et al., 2012). Some studies have found that hepatocytes release ATP into the extracellular, these extracellular ATP can act as autocrine or paracrine signal molecules to regulate liver function by activating purinergic receptors on the plasma membrane. Earlier studies have found that extracellular ATP and UTP nucleotides infusion into the liver can stimulate glycogen decomposition and glucose release in rat hepatocytes (Buxton et al., 1986). In later, Emmett and his team found that in human Huh7 cells expressing P2X4R and P2X7R, BzATP, a selective agonist of $\mathrm{P} 2 \mathrm{XR}(\mathrm{s})$, rapidly reduce the content of glycogen in Huh7 cells in the liver, which confirm that the activation of $\operatorname{P2XR}(s)$ could lead to glycogen decomposition, and $\operatorname{P} 2 \mathrm{XR}(\mathrm{s})$ also play an important role in the glycogen decomposition of ATP. Moreover, the inactivation of glucose-activated transcription factor (ChREBP) in glycogenrich hepatocytes leads to increased expression of P2X4R mRNA, which also suggests a functional relationship between P2XR(s) and glucose metabolism (Emmett et al., 2008). In addition, it was found that $\mathrm{P} 2 \mathrm{XR}(\mathrm{s})$ regulate bile formation in hepatocytes and bile duct cells by relying on extracellular ATP. P2X4R is a key regulator of chloride current in bile formation and alkalization induced by ATP in mouse bile duct epithelial cells. ATP is released from cholangiocytes into bile and is a potent secretagogue by increasing intracellular $\mathrm{Ca}^{2+}$ and stimulating fluid and electrolyte secretion via binding purinergic P2 receptors on the apical membrane (Woo et al., 2010). In their review, Fausther and his colleagues mentioned that $\operatorname{P} 2 X R(s)$ activation can regulate ionic secretion in hepatocytes and cholangiocytes. For example, in murine and human hepatocytes, activation of P2X4R and P2X7R leads to increased $\mathrm{Ca}^{2+}$ and $\mathrm{Na}^{+}$influxes, in rat hepatoma HTC cells, P2X4R activation modulates cellular regulatory volume decrease response by controlling the opening of volumesensitive rectifying outwardly $\mathrm{Cl}^{-}$channels. In $\mathrm{Mz}-\mathrm{Cha}-1$ bile duct cells, the addition of $\mathrm{Cu}^{(2+)}$ to extracellular medium could inhibit $\mathrm{Cl}^{-}$-current induced by BzATP, indicating that $\mathrm{P} 2 \mathrm{XR}(\mathrm{s})$ are also involved in ion secretion of bile duct cells (Fausther et al., 2012). In addition, in the mechanism of regulating liver regeneration and apoptosis, Gonzales and his team proposed that hepatocytes and Kupffer cells release large amounts of extracellular ATP, and promote liver regeneration after partial hepatectomy in rats. Interestingly, P2X4R was widely expressed in hepatocytes and Kupffer cells, mainly in the subtubule region closely related to lysosomal labeling. After partial hepatectomy, limited hepatocyte regeneration is observed in P2X4R knockout mice, accompanied by hepatocyte necrosis and cholestasis, impaired bile adaptability, changes in bile composition, and decreased release of adenosine triphosphate, and lysosomal enzymes. It is speculated that $\mathrm{P} 2 \mathrm{X} 4 \mathrm{R}$ purinergic signal contributes to the control of bile homeostasis through mechanisms involving peritubular lysosomes, thus protecting the liver from bile injury and hepatocyte proliferation after partial resection (Gonzales et al., 2010; Besnard et al., 2016). Interleukin-22 (IL-22) is released by immune cells and mediates strong hepatoprotective functions. In vivo-specific inhibition of $\mathrm{P} 2 \mathrm{X} 1$ was associated with decreased IL-22 secretion, elevated liver injury, and impaired liver regeneration (Kudira et al., 2016). More interestingly, the study also found that $\mathrm{P} 2 \mathrm{X} 7 \mathrm{R}$ is involved in the regulation of programmed cell death in hepatocytes and NKT cells. The intracellular calcium concentration was increased by extracellular ATP, which mediates calcium-dependent cell death (Zoetewij et al., 1996). It is reported that high concentrations of BzATP (P2X7R agonist) and extracellular ATP can stimulate P2X7R to induce a large amount of $\mathrm{Ca}^{2+}$ influx and lead to apoptosis in rat hepatocytes in vitro (Gonzales et al., 2007). Therefore, we concluded that P2XR(s) play a key role in regulating liver glucose metabolism, bile formation, ion secretion, hepatocyte regeneration, and apoptosis. At the same time, $\mathrm{P} 2 \mathrm{XR}(\mathrm{s})$ are also expressed in liver immune cells; thus, the study of $\mathrm{P} 2 \mathrm{XR}(\mathrm{s})$ in liver immunology and inflammation has received great attention, although $\mathrm{P} 2 \mathrm{X} 1 \mathrm{R}$ and P2X4R seem to be involved in this (Ulmann et al., 2010; Fiebich et al., 2014), the role of P2X7R in inflammation has been best studied, probably because almost all congenital and adaptive immune cells express it (Monif et al., 2010; Di Virgilio et al., 2017). Adenosine triphosphate (ATP) is secreted from hepatocytes under physiological conditions and plays an important role in liver biology by activating P2 receptors. In contrast, injury or infection induces the release of ATP from cells, which triggers inflammation by activating P2X7R on immune cells to induce the release of inflammatory cytokines (Burnstock, 2016b). Therefore, the P2XR(s) act as a danger signal and enhance the immune response, such as viral hepatitis, alcoholic hepatitis, drug-induced hepatitis, autoimmune hepatitis, liver fibrosis, and liver cancer. 


\section{P2X Receptors and Viral Hepatitis}

To explore the mechanism of hepatitis $C$ virus-induced liver pathogenesis in chronic hepatitis $\mathrm{C}$, Ashraf and his team showed that the expression of ionic purine $\mathrm{P} 2 \mathrm{XR}(\mathrm{s})$ on peripheral blood mononuclear cells (PBMC) of HCV patients is increased, mainly P2X1R and P2X7R, confirming the important participation of $\mathrm{P} 2 \mathrm{XR}(\mathrm{s})$ in $\mathrm{PBMC}$-mediated immune response in chronic HCV infection (Ashraf et al., 2013). Another study also confirmed that $\mathrm{P} 2 \mathrm{XR}(\mathrm{s})$ also exist in human hepatocytes (Huh-7 cell line), in which P2X4R reacts to HCV structural protein E1E2, suggesting that $\mathrm{P} 2 \mathrm{X} 4 \mathrm{R}$ may be involved in the pathological process of HCV (Manzoor et al., 2011, 2016).

\section{P2X Receptors and Alcohol-Associated Hepatitis}

In alcoholic steatohepatitis, mice exposed to alcohol directly lead to an increase in serum and extracellular ATP, inducing inflammasome activation and IL- $1 \beta$ to produce damage to liver cells. Interestingly, liver steatosis was attenuated in P2X7R knockout mice (Iracheta-Vellve et al., 2015). Freire and his team used C57BL/6 J mice to be exposed to a chronic mixture of ethanol and high-fat diet. Treatment with P2X7R antagonist A804598 reverses the changes in microglia and astrocytes and reduced mRNA levels of inflammatory markers (including IL-1 $\beta$, iNOS, and CXCR2) and inflammatory signal transduction pathways (such as TLR2, CASP1, NF-kB1, and CREB1), as well as protein levels of Pro-IL-1 $\beta$ and Nf-kB1. It is suggested that P2X7R antagonist A804598 has a protective effect on inflammatory liver injury induced by chronic ethanol and high-fat diet (Freire et al., 2019). In addition, it was found that gentiopicroside ameliorates have a protective effect on alcoholic fatty liver induced by acetaldehyde in acute and chronic alcoholic fatty liver model, and could inhibit the activation of NLRP3 inflammasome thereby inhibiting the production of IL- $1 \beta$ and Caspase-1 by inhibiting the P2X7R (Li et al., 2018b). Li and his colleagues also found that Pleurotus citrinopileatus aqueous extract inhibits inflammation by regulating SIRT1-AMPK sum to improve alcoholic hepatic steatosis and inhibit the activation of P2X7R-NLRP3 inflammatory bodies, thus achieve the purpose of treating alcoholic fatty liver (Li et al., 2018a).

\section{P2X Receptors and Drug-Induced Liver Injury}

In the mouse liver inflammation model induced by acetaminophen (APAP), excessive APAP can lead to liver injury and even hepatocyte necrosis, the impairment of dynamic balance of intracellular calcium $\left(\mathrm{Ca}^{2+}\right)$ is a sign of hepatocyte toxicity induced by acetaminophen (APAP). The report of Amaral and his team showed that extracellular ATP produces and activates P2XR(s) in the process of hepatocyte injury induced by APAP. P2XR(s) ion channel opens a large number of $\mathrm{Ca}^{2+}$ influx. The balance of intracellular $\mathrm{Ca}^{2+}$ is disrupted, which aggravated the liver injury. $\mathrm{P} 2 \mathrm{XR}(\mathrm{s})$ antagonist significantly eliminates the increase of intracellular calcium signal mediated by ATP (Amaral et al., 2013).
In addition, in the process of liver injury and necrosis, increases extracellular ATP-activated P2X7R can also promote immune response and inflammatory response leading to liver caspase-1 and neutrophil migration to the liver, and activate the inflammatory corpuscular NLRP3 to release and process inflammatory factors, such as IL-1 $\beta$, thus aggravating liver injury (Hoque et al., 2012). However, other studies have reported that P2X7R's antagonist A-438079 protects the liver by affecting metabolism not by inflammasome activation, reduces glutathione GSH consumption by inhibiting $\mathrm{P} 450$ isoenzymes, reduces liver and mitochondrial protein adducts, reduces JNK activation, and promotes mitochondrial P-JNK translocation, oxidative stress, and liver injury (Xie et al., 2013).

\section{P2X Receptors and Autoimmune Hepatitis}

It has been found that CD39 and P2XR(s) are expressed on NKT cells in mouse liver. CD39 regulates the production of nucleotide-mediated cytokines and limits their apoptosis through liver NKT cells, while autoimmune hepatitis induced by concanavalin $\mathrm{A}(\mathrm{Con} \mathrm{A})$ is mainly liver NKT cell-mediated, Beldi and his team's experimental results show that CD39 knockout is related to $\mathrm{P} 2 \mathrm{XR}(\mathrm{s})$ activation and NKT cell apoptosis in Con A-induced autoimmune hepatitis. Knockout of CD39 has protective effect on autoimmune hepatitis induced by Con A (Beldi et al., 2008). However, another study reported that there are two situations in which P2X7R regulates NKT cells in autoimmune hepatitis. The binding of P2X7R to NKT cells inhibits the immature cells of NKT cells and stimulates activated cells. Therefore, P2X7R can inhibit or promote autoimmune hepatitis (Kawamura et al., 2006).

\section{P2X Receptors and Liver Fibrosis}

$\mathrm{P} 2 \mathrm{X}$ receptor(s) also play an important role in liver fibrosis. Liver fibrosis is a wound healing response to liver injury induced by many factors, including hepatitis virus infection, alcohol, autoimmune diseases, or drugs. During chronic liver injury, resting hepatic stellate cells are activated into myofibroblast-like phenotypes, which are characterized by high expression of smooth muscle $\alpha$-actin ( $\alpha$-SMA) and deposition of large amounts of extracellular matrix, including type I collagen. Activated hepatic stellate cells produce inflammatory cytokines or chemokines under the action of interleukin- $1 \beta$, tumor necrosis factor- $\alpha$, or transforming growth factor $-\beta$ signals. These inflammatory factors can promote the synthesis of extracellular matrix, promote cell proliferation, and lead to liver fibrosis (Bataller and Brenner, 2005; Bieghs and Trautwein, 2013; Robert et al., 2016). In previous reports, P2X7R is described as a "risk sensor," which plays a key role in the release of danger signal ATP and drives inflammatory effectors activated by bacterial products to secrete inflammatory cytokines (Ferrari et al., 2006). In most cases, the elimination of pathogens requires damage-related molecular patterns (DAMP), including harmful endogenous cellular molecules released by necrotic cells (Rubartelli and Lotze, 2007). Extracellular ATP is an effective DAMP molecule, which induces the accumulation of NALP-3 inflammatory bodies by activating P2X7R and reducing intracellular 
$\mathrm{K}^{+}$. NALP-3 activates caspase-1 to induce pre-interleukin-1 (ProIL-1) maturation. IL-1 may upregulate different signal pathways through autocrine and paracrine signals, resulting in the increase of fibrogenic transforming factor- $\beta 1$ (TGF- $\beta 1$ ), the central mediator of fibrosis response in various tissues (Figure 3). This leads to fibrosis (LeRoy et al., 1990; Mariathasan and Monack, 2007; Gentile et al., 2015). From the study of the role of P2X7R in the activation of hepatic stellate cells by Jiang and his colleagues, it was found that the expression of Caspase-1mRNA, NLRP3mRNAlike receptor family (NLRP3mRNA) $\beta$, IL-1mRNA, IL-18, IL-6mRNA, and P2X7R is increased after LX-2 cells were directly treated with lipopolysaccharide (lps), and all of them are inhibited by P2X7R antagonist. Therefore, it is concluded that the activation of NLRP3 inflammatory bodies mediated by P2X7R may be involved in the production of IL-1 $\beta$ in hepatic stellate cells, and blocking the axis of P2X7R-NLRP3 inflammatory bodies may be a potential target for the treatment of hepatic fibrosis (Jiang et al., 2017). Huang and his team used an antagonist (A438079) to inhibit P2X7R to block collagen deposition and significantly reduce the expression of $\alpha$-smooth muscle actin $(\alpha-S M A)$ and TGF- $\beta 1$ (Huang et al., 2014). Tung and his colleagues also showed that P2X7R antagonist brilliant blue (BBG) downregulates TGF- $\beta$ signal pathway and significantly decreases the expression of pro-inflammatory cytokines IL-6, IL-1 $\beta$, and

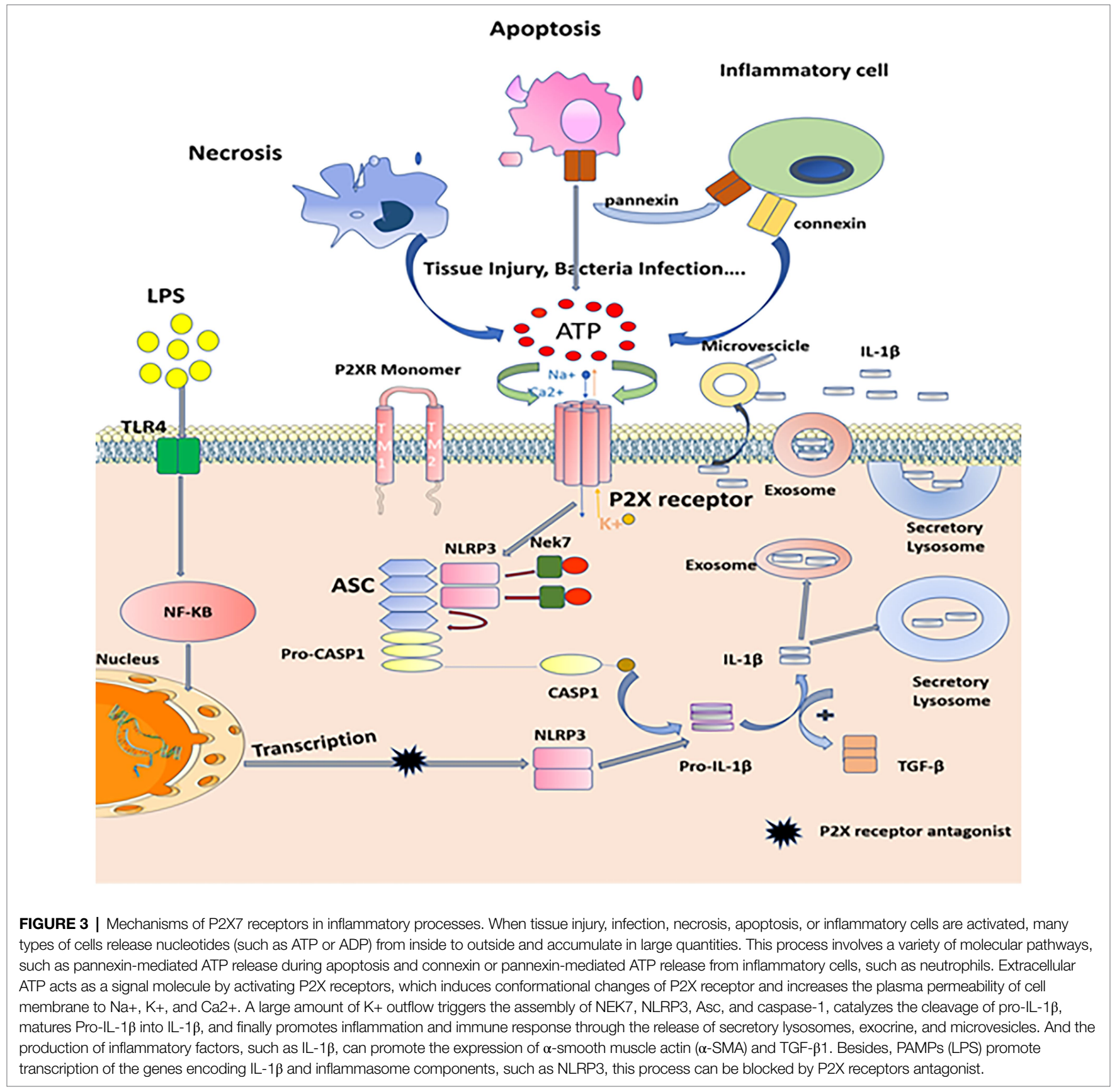


TNF- $\alpha$ in cirrhotic rats induced by choledochal ligation, and suggested that blocking P2X7R may be a therapeutic target for liver fibrosis and its complications (Tung et al., 2015). These reports confirmed the important role of $\mathrm{P} 2 \mathrm{X} 7 \mathrm{R}$ in liver fibrosis. In 2020, Jiang et al. explored the role of P2X7R in hepatic fibrosis induced by thioacetamide (TAA) and the mechanism of macrophage P2X7R promoting fibrosis. It was found that A438079, an antagonist of P2X7R, could reverse TAA-induced liver injury and fibrosis by antagonizing the activation of P2X7R-TLR4-NLRP3 axis (Jiang et al., 2020). Interestingly, in alcoholic liver fibrosis, P2X7R mediates acetaldehyde-induced activation of hepatic stellate cells through PKC-GSK3 $\beta$ signaling pathway, which promotes protein kinase $\mathrm{C}$ (PKC)/glycogen synthase kinase-3 $\beta$ (GSK3 $\beta$ )-dependent HSC proliferation and collagen production. P2X7R inhibitors may be a new drug for the treatment of alcoholic liver fibrosis (Wu et al., 2017). In addition, excepting P2X7R and P2X4R have also been reported to play a role in hepatic fibrosis. Studies by Le Guilcher and his team have found that increased expression of P2X4R stimulates calcium entry and lysosomal exocytosis, thereby releasing ATP and activating P2X4R-mediated signals by regulating cell contraction, adhesion and migration, and driving (HMF) activation in liver fibroblasts by controlling matrix synthesis degradation balance. As a result, the accumulation of extracellular matrix induces liver fibrosis, which is significantly attenuated when the P2X4R gene is knocked out or is inhibited by pharmacology (Le Guilcher et al., 2018). Therefore, P2XR(s) play a key role in the occurrence and development of liver fibrosis and provide a new target and direction for the treatment of liver fibrosis.

\section{P2X Receptors and Sepsis}

Sepsis is a life-threatening organ dysfunction caused by a dysregulated host response to infection (Singer et al., 2016). Sepsis is mainly caused by inappropriate regulation of the immune system (Oberholzer et al., 2001; Benjamim et al., 2004), this dysregulation manifests as an inability to control bacterial growth and dissemination and by excessive inflammation, processes that are interrelated and are caused, in large part, by macrophage dysfunction (Csóka et al., 2015). In addition, macrophages are the primary P2X7R-expressing cell type (Gu et al., 2000). Csóka and his team found increased ATP levels in the plasma of septic mice, indicating increased extracellular ATP release, their results indicate that P2X7R signaling on myeloid cells augments intracellular killing of bacteria in sepsis (Csóka et al., 2015). Except for the P2X7R, Csóka and his team in a later study found Macrophage P2X4R augment bacterial killing and protect against sepsis, pharmacological targeting of $\mathrm{P} 2 \mathrm{X} 4 \mathrm{R}$ with the allosteric activator ivermectin protects against bacterial dissemination and mortality in sepsis (Csóka et al., 2018). The severity of sepsis can be linked to excessive inflammatory responses resulting in hepatic injury, P2X7R activation by e-ATP exacerbates inflammation by augmenting cytokine production, while CD39 (ENTPD1) scavenges e-ATP to generate adenosine, thereby limiting $\mathrm{P} 2 \mathrm{X} 7$ activation and resulting in A2A receptor stimulation (Savio et al., 2017). Savio and his team found that CD39 expression in macrophages limits ATP-P2X7R-mediated pro-inflammatory responses. Moreover, the combination of $\mathrm{P} 2 \mathrm{X} 7$ blockade with an adenosine $\mathrm{A} 2 \mathrm{~A}$ receptor agonist (ATL146e) completely protects the liver during sepsis, improving experimental outcomes (Savio et al., 2017). Larrouyet-Sarto et al. confirmed that $\mathrm{P} 2 \mathrm{X} 7$ receptor expression increases in the liver of septic, when the P2X7R genetic deletion attenuates liver injury in septic mice and reduces oxidative stress induced by hepatic septicaemia in mice and reduces the number of inflammatory cells in liver tissue from septic mice. Therefore, these findings suggest possible administration of P2X7 receptor blockers to limit oxidative damage, inflammation, and liver injury during the acute phase of sepsis (Larrouyet-Sarto et al., 2020).

\section{P2X Receptors and Liver Cancer}

In the study of Asif and his team, it was found that the expression of P2X4R and P2X7R is significantly increased in human hepatocellular carcinoma and hepatocellular adenocarcinoma compared with the control group. It is concluded that P2X4R and P2X7R are closely related to the downstream process of inflammation by activating inflammatory bodies, oxidative stress, and immune regulation, thus promoting the sustainable development of cancer and speculating that these two receptors are closely related to the quality of the tumor (Asif et al., 2019). Previous studies have shown that PI3K/Akt signaling pathway can be activated in hepatocellular carcinoma, and the activation of Akt is closely related to the invasiveness of HCC (Nakanishi et al., 2005). In addition, Ghalali and his team confirmed that Atto vastatin can reduce hepatitis $B$ virus $\mathrm{X}$ protein-( $\mathrm{HBx})$ and insulin-induced PACT and pGsk3 $\beta$ levels, and antagonize Akt-induced adipogenesis, but these effects depend on P2XR(s). Therefore, we concluded that the imbalance of AKT pathway may promote the development of hepatocellular carcinoma, and P2X-AKT signal pathway may play an important role in the anti-cancer effect of statins (Ghalali et al., 2017).

\section{PANCREAS}

The pancreas is a complex glandular organ with exocrine and endocrine. Some studies have confirmed that $\operatorname{P2XR}(\mathrm{s})$ are widely expressed in the pancreas, mainly expressed in the pancreatic duct cells, islet beta 1 cells, HIT cells, islet Beta-TC6 cells, pancreatic stellate cells, and pancreatic ductal adenocarcinoma cell line. It also plays an important role in exocrine, endocrine, $\beta$-cell apoptosis, and sensory signal transmission in the pancreas (Lynch et al., 1999; CoutinhoSilva et al., 2001; Ohtani et al., 2011). First of all, a number of experimental studies have confirmed that P2X7R is expressed in the pancreatic duct, which can induce the increase of intracellular $\mathrm{Ca}^{2+}$ concentration under the action of ATP (Christoffersen et al., 1998; Wang et al., 2013). Knockout of pancreatic P2X7 receptors leads to a decrease in $\mathrm{Ca}^{2+}$ signal, which eventually leads to a significant decrease in pancreatic ductal secretion; however, there is a gender difference in this mode of induction (Novak et al., 2010). In terms of pancreatic endocrine regulation, $\mathrm{P} 2 \mathrm{X} 3, \mathrm{P} 2 \mathrm{X} 4$, and $\mathrm{P} 2 \mathrm{X} 7$ receptor have 
been identified in INS- $1 \beta$ cells, mouse, rat, and human pancreatic $\beta$ cells, and it has been confirmed that $\mathrm{p} 2 \mathrm{XR}(\mathrm{s})$ in pancreatic $\beta$ cells are involved in insulin secretion, glucose metabolism, and $\beta$-cell apoptosis (Lynch et al., 1999; CoutinhoSilva et al., 2001; Ohtani et al., 2011). It has been found that insulin release is triggered by intracellular $\mathrm{Ca}^{2+}$ concentration and has a certain glucose concentration dependence. The increase of $\mathrm{Ca}^{2+}$ concentration in cells can trigger insulin secretion vesicles containing insulin to release insulin through exocytosis, and extracellular ATP activates $\mathrm{P} 2 \mathrm{X}$ receptor to open the receptor ion channel pore to mediate $\mathrm{Ca}^{2+}$ influx, thus regulating insulin release (Burnstock, 2014). In the report of Geschwind and his team, hamster cloned $\beta$-cell line HIT cells are selected to confirm that ATP stimulated $\mathrm{Ca}^{2+}$ influx rather than $\mathrm{Ca}^{2+}$ storage and release, suggesting that the receptor manipulated the channel may be P2XR(s) (Geschwind et al., 1989). It has been reported that P2XR(s) in rat $\beta$ cells are activated by ATP or P2XR(s) agonist $\alpha$, $\beta$-meATP at low or non-stimulating glucose concentration, which induces transient insulin release (Coutinho-Silva et al., 2001; Burnstock, 2014). In human $\beta$ cells, ATP activates ionic $\mathrm{P} 2 \mathrm{X} 3 \mathrm{R}$ in the plasma membrane of $\beta$ cells, opening the pores of P2X3R ion channels, resulting in the influx of $\mathrm{Ca}^{2+} / \mathrm{Na}^{+}$, resulting in membrane depolarization, and action potential frequency increasing the $\mathrm{Ca}^{2+}$ flux through your high voltagegated $\mathrm{Ca}^{2+}$ channels, thereby stimulating insulin release. At the same time, insulin vesicles also contain a certain amount of ATP, so the simultaneous release of ATP and insulin and the activation of P2XR(s) amplify glucose-induced insulin release, thus making the secretion mechanism of $\beta$ cells more sensitive (Jacques-Silva et al., 2010). Similarly, it has been confirmed that $\mathrm{P} 2 \mathrm{X} 4 \mathrm{R}$ is also involved in the regulation of insulin secretion in mouse islet Beta-TC6 cells and is related to the regulation of islet cell proliferation and cell viability (Ohtani et al., 2011). The study also found that P2X7R regulates the quality of islet cells by regulating the secretion of IL-1 and is related to $\beta$-cell apoptosis in the later stage of type 2 diabetes (Giannuzzo et al., 2015). So far, many studies have reported that $\mathrm{P} 2 \mathrm{XR}(\mathrm{s})$ play an important role in acute pancreatitis, chronic pancreatitis, diabetes, and pancreatic cancer.

\section{P2X Receptors and Acute Pancreatitis}

Acute pancreatitis (AP) is a kind of aseptic inflammation with high annual incidence, and about $20 \%$ of patients develop into severe Acute pancreatitis (SAP), with high mortality. It is characterized by early activation of intracellular proteases followed by acinar cell death and inflammation. In murine acute pancreatitis induced by Hoque and his colleagues with caerulein, TLR9 and P2X7R are important DAMP receptors upstream activated by inflammatory bodies. The use of P2X7R antagonist AME 439079 can reduce the pancreatic edema and significantly reduce pancreatic leukocyte infiltration (Hoque et al., 2011). In addition, Zhang and his team confirmed that the emodin reduces the concentration of IL- $1 \beta$ and IL-18 in plasma by inhibiting P2X7R/NLRP3 signal pathway in rats with acute pancreatitis, thus limiting the progress of SAP (Zhang et al., 2019).

\section{P2X Receptors and Chronic Pancreatitis}

It was reported as early as 1995 that inflammatory cell infiltration, progressive organ atrophy, and disorder of collagen deposition occurred in chronic pancreatitis (Steer et al., 1995). Extracellular nucleotides are regarded as important mediators of inflammation in many pathological situations. Künzli and his team propose the role of purinergic signal transduction in the chronic pancreatitis; their study confirmed a significant increase in transcripts of exonucleases and P2R (P2X7R, P2Y2R, and P2Y6R) in chronic pancreatitis and is associated with chronic inflammation and neoplasia of the pancreas (Künzli et al., 2007). As is known to all, chronic pancreatitis results in organ fibrosis, pain, and exocrine and endocrine insufficiency. The formation of fibrosis and pain are important characteristics of chronic pancreatitis, activation of pancreatic stellate cells (PSC) plays a key role in pancreatic fibrosis. Inflammation and repetitive pancreatic injury lead to cytokine-mediated activation and oxidative damage to cells, with the potential to increase extracellular nucleotide release and accumulation, extracellular nucleotides regulate inflammation, and immunity via purinergic/pyrimidinergic P2-receptors (P2XR and P2YR), extracellular nucleotides are hydrolyzed by ecto-enzymes, such as nucleoside triphosphate diphosphohydrolase-1 (CD39/NTPDase-1; Dranoff et al., 2002). It is reported that PSC expresses P2X7R at mRNA transcripts and protein levels. CD39 deletion decreases fibrogenesis in experimental pancreatitis. Therefore, extracellular nucleotides and P2X7R are important regulators of the PSC proliferation and death (Künzli et al., 2008; Haanes et al., 2012). In addition, p2XR(s) are associated with the pain mechanism of chronic pancreatitis. In the rat, model of chronic pancreatitis induced by trinitrobenzene sulfonic acid (TNBS). TNBS injection produced a significant upregulation of $\mathrm{P} 2 \mathrm{X} 3 \mathrm{R}$ expression and an increase in ATP-evoked responses of pancreatic DRG neurons. Pancreatic hyperalgesia is markedly attenuated by administration of purinergic receptor antagonist suramin (Wang et al., 2015).

\section{P2X Receptors and Diabetes}

Interestingly, P2XR(s) are also involved in mediating insulin secretion, survival, and apoptosis of islet $\beta$ cells, indicating that $\mathrm{P} 2 \mathrm{XR}(\mathrm{s})$ also play a role in diabetes. We all know that type 1 and type 2 diabetes are inflammatory diseases. P2X7R knockout mice can prevent type 1 diabetes induced by streptozotocin and limit the increase in levels of pro-inflammatory mediators (IL- $1 \beta$, interferon- $\gamma$, and nitric oxide; Vieira et al., 2016). In STZ-induced diabetic rats, the P2X7R on the glucagon-containing alpha cells in the islets is increased, and they migrate in the center to replace the missing insulin-containing $\beta$ cells (Coutinho-Silva et al., 2003). Other studies have shown that P2X7R inhibition can be used as an adjuvant therapy to delay the progression of diabetic nephropathy (Rodrigues et al., 2014). 


\section{P2X Receptors and Pancreatic Cancer}

In recent years, $\mathrm{P} 2 \mathrm{XR}(\mathrm{s})$ have also been reported in pancreatic cancer, and it has been found that the expression of P2X7R is upregulated in pancreatic cancer and chronic pancreatitis (Künzli et al., 2007). In 2015, Giannuzzo and his team confirmed that $\mathrm{P} 2 \mathrm{X} 7$ is overexpressed in human pancreatic ductal adenocarcinoma cell line (PDAC), and regulated the survival, migration, and invasion of pancreatic ductal adenocarcinoma cells, in which P2X7R had different effects on PDAC cell survival. Specific P2X7R'S agonist BzATP had cytotoxic effect on all cell lines and mediated cell necrosis, and P2X7R pore antagonist A438079 inhibited the proliferation of all PDAC cell lines (Giannuzzo et al., 2015, 2016). In the treatment of pancreatic cancer, some studies have reported the progress of statins in inhibiting PDAC by targeting the P2X7-Akt axis or P3IK/Akt signal and making pancreatic cancer cells sensitive to chemotherapeutic drugs (Mistafa and Stenius, 2009; Mohammed et al., 2012).

\section{INTESTINE}

In the gutl tract, $\mathrm{P} 2 \mathrm{XR}(\mathrm{s})$ are mainly distribute in the submucosal nerve plexus of the intestinal tract, myenteric nerve plexus, both longitudinal and circular muscle of the colon, intestinal epithelial cancer cells (HCT8 and Caco-2), and colorectal cancer cells. There are also differences in the expression of the P2XR(s) subtype, in which $\mathrm{p} 2 \mathrm{X} 2 \mathrm{R}, \mathrm{P} 2 \mathrm{X} 3 \mathrm{R}, \mathrm{P} 2 \mathrm{X} 5 \mathrm{R}$, and $\mathrm{P} 2 \mathrm{X} 6 \mathrm{R}$ are express in myenteric plexus and Submucosal plexus. P2X6R mainly expressed on intrinsic sensory neurons, such as in the large size neurons which resembled Dogiel type II neurons and NeuN-ir cells, may be involved in regulating the physiological functions of these neurons. In addition, P2X4R expressed in macrophages of the rat gastrointestinal tract and $\mathrm{p} 2 \mathrm{X} 7 \mathrm{R}$ mainly expressed in colorectal cancer cells. It was found that P2X2R is immunoreactive in the intermuscular neurons of the longitudinal and circular muscles of the colon, which are mainly involved in mediating the contraction of colonic muscle (Giaroni et al., 2002). Therefore, P2XR plays an important role in intestinal diseases, such as intestinal hypersensitivity, inflammatory bowel disease, intestinal transport disorders, and intestinal tumors.

\section{P2X Receptors and IBS}

Irritable bowel syndrome (IBS) is a functional bowel disorder that presents with no structural and biochemical abnormalities, and it is clinically characterized by abdominal pain, abdominal distention, alterations in bowel habits, and changes in stool characteristics. The present pathogenesis of IBS remains unclear. The most important mechanisms recently implicated in the genesis of IBS symptoms are the abnormal intestinal motility, changes in the function of the sensory, and the enhanced intestinal nociception. According to the report that $\mathrm{p} 2 \mathrm{XR}(\mathrm{S})$ are distributed on subsets of myenteric and submucous neurons of the ENS, glia, ICC, smooth muscle, epithelia and EC cells, and immunochemical. Electrophysiological and calcium imaging studies confirmed the role of $\mathrm{P} 2 \mathrm{X}(\mathrm{s})$ ion channel receptors in excitatory neurotransmission and information transfer between neurons and glia cells. ATP is a danger signal molecule in the gastrointestinal tract and its release is likely mediated from both local epithelial cells and nerves to modulate peristalsis, secretion, and nociception. Early studies have shown that in the process of visceral hyperalgesia and visceral hypersensitivity induced by IBS in rats, colonic dilated intestinal epithelial cells release ATP to activate P2XR(s) (P2X3R) innervating colonic afferent nerve endings, which mediates mechanical sensory transduction, such as visceral pain and hypersensitivity (Wynn et al., 2003; Xu et al., 2008). In a model without colonic inflammation, Shinoda and his team have shown that P2X3R mediates different colonic mechanosensitivity and colon zymosan hypersensitivity in mice (Shinoda et al., 2009). In addition, in the rat model of diabetic colonic hypersensitivity induced by streptozotocin (STZ), it was found that the excitability and P2X3R expression of rat colon-specific dorsal root ganglion (DRG) neurons are increased, and this effect could be inhibited by lipoic acid (ALA), which provides a new therapeutic target for diabetic colonic hypersensitivity ( $\mathrm{Hu}$ et al., 2017). AIEC LF82 infection can increase the expression of P2X4R and $\mathrm{P} 2 \mathrm{X} 7 \mathrm{R}$ in CEABAC10 hypersensitive mice. P2X3R exists in the sensory neurons of the central nervous system and the peripheral nervous system, is activated by low levels of ATP, and can be sensitized after inflammation or nerve injury (Lashermes et al., 2018). Therefore, P2XR(s) antagonists are of great significance in the treatment of IBS. Due to pain, diarrhea, constipation, and pain are the characteristic symptoms of IBS, so it is necessary to target and antagonize these symptoms, respectively. Relevant literature shows that $\mathrm{P} 2 \mathrm{X} 2 / 3 \mathrm{R}, \mathrm{P} 2 \mathrm{X} 3 \mathrm{R}$, and $\mathrm{P} 2 \mathrm{X} 7 \mathrm{R}$ antagonists are potential drugs for visceral pain and that includes A-317491, AF-353, and TNP-ATP. Several diaminopyridines were shown to be selective antagonists at P2X3R and P2X2/3R, and had in vivo efficacy in a pain model (Ballini et al., 2011). For diarrhea and constipation, agonists acting at enteric P2XR(s) may enhance gastrointestinal propulsion and secretion, and these drugs could be useful for treating constipationpredominant IBS and antagonists acting at enteric P2XR(s) would decrease propulsion and secretion and they might be useful for treating diarrhea-predominant IBS (Galligan, 2004).

\section{P2X Receptors and IBD}

According to the related literature, the role of $\mathrm{P} 2 \mathrm{XR}(\mathrm{s})$ has been explored in the pathological mechanism of IBD. Inflammatory bowel disease (IBD) is a kind of chronic intestinal disease, which mainly includes Crohn's disease (CD) and ulcerative colitis (UC). In recent years, some teams have proposed that the overactivation of intestinal immune cells (including macrophages and $\mathrm{T}$ helper cells) promotes the progress of IBD in the pathogenesis of IBD (Brown and Mayer, 2007). Interestingly, a large amount of extracellular ATP produced by inflammatory injury promotes immune response and inflammatory response by activating $\mathrm{P} 2 \mathrm{XR}(\mathrm{s})$. The expression of $\mathrm{P} 2 \mathrm{X} 3 \mathrm{R}$ is increased in the myenteric 
plexus of human colitis and is significantly upregulated in inflammation and hypersensitivity, suggesting that it plays a role in dyskinesia and pain (Yiangou et al., 2001; Wynn et al., 2004). In the report of Zoetewij and his team, it was pointed out that in the rat colitis model induced by sodium dextran sulfate (DSS), P2XR(s)'s antagonist blocked ATP-P2X7R signal transduction and inhibited the activation of NF $\kappa \mathrm{B}$ and the expression of caspase-1 in lamina propria immune cells, thus inhibiting the levels of TNF and IL-1 $\beta$. Therefore, antagonistic P2X7R can limit the development of IBD. However, Hofman and his team suggest that in the treatment of IBD with $\mathrm{P} 2 \mathrm{X} 7$ receptor antagonists, it limits intestinal inflammation and promotes the proliferation of intestinal epithelial cells, which protects intestinal epithelial cells from apoptosis, besides, it increases the risk of colitisassociated cancer (CAC; Hofman et al., 2015). Both inflammatory bowel disease (IBD) and irritable bowel syndrome (IBS) are characterized by visceral abdominal pain with colonic hypersensitivity (CHS). Some studies have shown that P2X3R is not involved in sensory transmission under physiological conditions but is mainly transduced in the intracellular environment through extracellular ATP binding to P2X3R signal in the late stage of acute TNBS colitis and inflammation, including Cdk5. Csk and CASK kinases regulate colonic hypersensitivity, suggesting that P2X3R is a potential new target for the treatment of abdominal pain syndrome (Volonté and Burnstock, 2013; Deiteren et al., 2015). In the Lashermes team study, transgenic mice expressing intestinal CEACAM6 receptors were used to study whether AIEC LF82 infection led to the development of colonic hypersensitivity. It was found that colonic hypersensitivity induced by AIEC LF82 bacteria is associated with increased expression of P2X3R, P2X4R, and P2X7R (Lashermes et al., 2018). Therefore, knocking out or antagonizing $\mathrm{P} 2 \mathrm{X} 7$ receptor is a new target for the treatment of IBD. Research shows that AZD9056 is an adamantane amide and selective P2X7R antagonist, being evaluated for safety and efficacy in causing clinical remission in CD patients - This is the first clinical trial in IBD patients with a P2X antagonist. Additional phase I and II clinical trials are currently underway regarding the safety and efficacy of P2X7R antagonists. It is believed that P2XR(s) antagonists will become an important target of IBD in the near future.

\section{P2X Receptor and Intestinal Cancer}

In recent years, it has been found that $\mathrm{P} 2 \mathrm{XR}(\mathrm{s})$ also play an important role in intestinal tumors. $\mathrm{P} 2 \mathrm{XR}(\mathrm{s})$ participate in the regulation of proliferation and apoptosis of human intestinal epithelial cancer cells (HCT8 and Caco-2), and the action of high concentration of ATP activates P2X7R and induces cancer cell apoptosis (Coutinho-Silva et al., 2005). Some studies have shown that compared with normal tissues, P2X7R is overexpressed in colorectal cancer cells. Overexpressed P2X7R is closely related to tumor size, metastasis, and TNM stage of colorectal cancer. The expression of P2X7R may be a potential biomarker for judging prognosis and metastasis of colorectal cancer (Qian et al., 2017). In 2020, Zhang and his team confirmed that
P2X7R is involved in the activation of STAT3 signal and the regulation of EMT-related gene expression in colon cancer cells induced by ATP, and the activation of P2X7R can also stimulate STAT3 pathway and regulate the expression of MMP-2 and E-cadherin. These genes are the key factors of tumor cell migration and invasion, so we conclude that $\mathrm{P} 2 \mathrm{X} 7 \mathrm{R}$ promotes the invasion and migration of colon cancer. This may be an important potential target for the treatment of colon cancer (Zhang et al., 2020).

\section{CONCLUSION}

Undoubtedly, as research on P2XR(s) continues, the possibility of P2XR(s) become a therapeutic target for the treatment of diseases is advanced. Similarly, the physiology, pathology, and mechanism of P2XR(s) in digestive system have been revealed constantly. However, there are still some mechanisms that have not been fully clarified and even controversial. $\operatorname{P2XR}(s)$, as an ionic channel receptor, are mainly activated directly or indirectly by ATP as the main ligand, resulting in cell membrane depolarization, triggering action potentials, and transmitting a series of sensory signals to the nerve center, such as in the regulation of chronic visceral pain. $\mathrm{P} 2 \mathrm{X} 3 \mathrm{R}$ and $\mathrm{P} 2 \mathrm{X} 2 / 3 \mathrm{R}$ expressed in the primary sensory afferent nerves of the visceral vagus nerve can be activated by ATP to directly sensitize $C$ fibers through membrane depolarization and calcium entry, thus promoting the transmission of pain signals to the center. What is more, some of these subtypes (such as P2X7R) can activate a series of signaling pathways in cells, leading to a wide range of cellular responses, thus promoting the regulation of corresponding physiological and pathological functions. For example, under the condition of liver injury or infection, it can induce cells to release ATP molecules and activate P2X7R on liver immune cells to induce a large number of $\mathrm{K}^{+}$influx to activate the release of inflammatory corpuscles and process inflammatory cytokines which can cause liver inflammatory lesions, such as alcoholic hepatitis, liver fibrosis, and so on. In addition, in recent years, a large number of studies have confirmed that P2XR(s) play a key role in the invasion, metastasis, proliferation, and apoptosis of digestive system tumors, especially P2X7R has become a potential biomarker of prognosis and metastasis of many digestive system tumors and is closely related to cancer pain. Therefore, the development of P2XR(s) blockers can not only reduce cancer-related pain, but also delay tumor progression. It is believed that P2XR(s) may be a key therapeutic target for many digestive diseases in the future with increasing studies on the pharmacology of $\mathrm{P} 2 \mathrm{XR}(\mathrm{s})$ in the future.

\section{AUTHOR CONTRIBUTIONS}

QA and GY equally contributed to this study and wrote the manuscript. XY, JL, WS, YH, QD, and QL collected the literature. JX primarily revised and finalized the manuscript. RX revised 
the manuscript for clarity and style. All authors have read and approved the final manuscript. RX and JX are the co-corresponding authors.

\section{FUNDING}

This study was supported by research grants the National Natural Science Foundation of China (nos. 81660099, 82170628, 81970541, 31960151, and 32160208) and Collaborative Innovation

\section{REFERENCES}

Ahn, S. C., Xu, W. X., So, I., Kim, K. W., and Kang, T. M. (1995). Effects of purinergic agonists on mechanical and electrical activities of gastric smooth muscle of Guinea-pig. J. Smooth Muscle Res. 31, 407-410.

Amaral, S. S., Oliveira, A. G., Marques, P. E., Quintão, J. L., Pires, D. A., Resende, R. R., et al. (2013). Altered responsiveness to extracellular ATP enhances acetaminophen hepatotoxicity. Cell Commun. Signal. 11:10. doi: 10.1186/1478-811X-11-10

Ashraf, W., Manzoor, S., Ashraf, J., Ahmed, Q. L., Khalid, M., Tariq, M., et al. (2013). Transcript analysis of P2X receptors in PBMCs of chronic HCV patients: an insight into antiviral treatment response and HCV-induced pathogenesis. Viral Immunol. 26, 343-350. doi: 10.1089/vim.2013.0044

Asif, A., Khalid, M., Manzoor, S., Ahmad, H., and Rehman, A. U. (2019). Role of purinergic receptors in hepatobiliary carcinoma in Pakistani population: an approach towards proinflammatory role of $\mathrm{P} 2 \mathrm{X} 4$ and $\mathrm{P} 2 \mathrm{X} 7$ receptors. Purinergic Signal. 15, 367-374. doi: 10.1007/s11302-019-09675-0

Ballini, E., Virginio, C., Medhurst, S. J., Summerfield, S. G., Aldegheri, L., Buson, A., et al. (2011). Characterization of three diaminopyrimidines as potent and selective antagonists of $\mathrm{P} 2 \mathrm{X} 3$ and $\mathrm{P} 2 \mathrm{X} 2 / 3$ receptors with in vivo efficacy in a pain model. Br. J. Pharmacol. 163, 1315-1325. doi: 10.1111/j. 1476-5381.2011.01322.x

Banerjee, B., Medda, B. K., Schmidt, J., Zheng, Y., Zhang, Z., Shaker, R., et al. (2009). Altered expression of P2X3 in vagal and spinal afferents following esophagitis in rats. Histochem. Cell Biol. 132, 585-597. doi: 10.1007/ s00418-009-0639-4

Bataller, R., and Brenner, D. A. (2005). Liver fibrosis. J. Clin. Invest. 115, 209-218. doi: $10.1172 /$ JCI24282

Beldi, G., Wu, Y., Banz, Y., Nowak, M., Miller, L., Enjyoji, K., et al. (2008). Natural killer $\mathrm{T}$ cell dysfunction in $\mathrm{CD} 39$-null mice protects against concanavalin A-induced hepatitis. Hepatology 48, 841-852. doi: 10.1002/ hep. 22401

Benjamim, C. F., Hogaboam, C. M., and Kunkel, S. L. (2004). The chronic consequences of severe sepsis. J. Leukoc. Biol. 75, 408-412. doi: 10.1189/ jlb.0503214

Besnard, A., Gautherot, J., Julien, B., Tebbi, A., Garcin, I., Doignon, I., et al. (2016). The P2X4 purinergic receptor impacts liver regeneration after partial hepatectomy in mice through the regulation of biliary homeostasis. Hepatology 64, 941-953. doi: 10.1002/hep.28675

Bieghs, V., and Trautwein, C. (2013). The innate immune response during liver inflammation and metabolic disease. Trends Immunol. 34, 446-452. doi: 10.1016/j.it.2013.04.005

Blanke, E. N., Stella, S. L. Jr., Ruiz-Velasco, V., and Holmes, G. M. (2019). Purinergic receptor expression and function in rat vagal sensory neurons innervating the stomach. Neurosci. Lett. 706, 182-188. doi: 10.1016/j. neulet.2019.05.017

Brown, S. J., and Mayer, L. (2007). The immune response in inflammatory bowel disease. Am. J. Gastroenterol. 102, 2058-2069. doi: 10.1111/ j.1572-0241.2007.01343.x

Burnstock, G. (1972). Purinergic nerves. Pharmacol. Rev. 24, 509-581.

Burnstock, G. (1976). Purinergic receptors. J. Theor. Biol. 62, 491-503. doi: 10.1016/0022-5193(76)90133-8

Burnstock, G. (2014). Purinergic signalling in endocrine organs. Purinergic Signal. 10, 189-231. doi: 10.1007/s11302-013-9396-x
Center of Chinese Ministry of Education (2020-39) and the Graduate Research Fund Project of Guizhou Province [nos. YJSCXJH(2020)171 and YJSCXJH(2020)166].

\section{ACKNOWLEDGMENTS}

We thank Professor Biguang Tuo (Department of Gastroenterology, Affiliated Hospital to Zunyi Medical University) for highly professional services.

Burnstock, G. (2016a). Purinergic signalling in the gut. Adv. Exp. Med. Biol. 891, 91-112. doi: 10.1007/978-3-319-27592-5_10

Burnstock, G. (2016b). P2X ion channel receptors and inflammation. Purinergic Signal. 12, 59-67. doi: 10.1007/s11302-015-9493-0

Burnstock, G. (2018). Purine and purinergic receptors. Brain Neurosci. Adv. 2:2398212818817494. doi: 10.1177/2398212818817494

Buxton, D. B., Robertson, S. M., and Olson, M. S. (1986). Stimulation of glycogenolysis by adenine nucleotides in the perfused rat liver. Biochem. J. 237, 773-780. doi: 10.1042/bj2370773

Calik, I., Calik, M., Sarikaya, B., Ozercan, I. H., Arslan, R., Artas, G., et al (2020). P2X7 receptor as an independent prognostic indicator in gastric cancer. Bosn. J. Basic Med. Sci. 20, 188-196. doi: 10.17305/bjbms.2020.4620

Castelucci, P., Robbins, H. L., and Furness, J. B. (2003). P2X(2) purine receptor immunoreactivity of intraganglionic laminar endings in the mouse gastrointestinal tract. Cell Tissue Res. 312, 167-174. doi: 10.1007/s00441-003-0715-3

Cho, Y. R., Jang, H. S., Kim, W., Park, S. Y., and Sohn, U. D. (2010). P2X and $\mathrm{P} 2 \mathrm{Y}$ receptors mediate contraction induced by electrical field stimulation in feline esophageal smooth muscle. Korean J. Physiol. Pharmacol. 14, 311-316. doi: $10.4196 / \mathrm{kjpp} .2010 .14 .5 .311$

Christoffersen, B. C., Hug, M. J., and Novak, I. (1998). Different purinergic receptors lead to intracellular calcium increases in pancreatic ducts. Pflugers Arch. 436, 33-39. doi: 10.1007/s004240050601

Coutinho-Silva, R., Parsons, M., Robson, T., and Burnstock, G. (2001). Changes in expression of $\mathrm{P} 2$ receptors in rat and mouse pancreas during development and ageing. Cell Tissue Res. 306, 373-383. doi: 10.1007/s004410100458

Coutinho-Silva, R., Parsons, M., Robson, T., Lincoln, J., and Burnstock, G. (2003). P2X and P2Y purinoceptor expression in pancreas from streptozotocindiabetic rats. Mol. Cell. Endocrinol. 204, 141-154. doi: 10.1016/ S0303-7207(03)00003-0

Coutinho-Silva, R., Stahl, L., Cheung, K. K., de Campos, N. E., de Oliveira Souza, C., Ojcius, D. M., et al. (2005). P2X and P2Y purinergic receptors on human intestinal epithelial carcinoma cells: effects of extracellular nucleotides on apoptosis and cell proliferation. Am. J. Physiol. Gastrointest. Liver Physiol. 288, G1024-G1035. doi: 10.1152/ajpgi.00211.2004

Csóka, B., Németh, Z. H., Szabó, I., Davies, D. L., Varga, Z. V., Pálóczi, J., et al. (2018). Macrophage P2X4 receptors augment bacterial killing and protect against sepsis. JCI Insight 3:e99431. doi: 10.1172/jci.insight.99431

Csóka, B., Németh, Z. H., Törő, G., Idzko, M., Zech, A., Koscsó, B., et al. (2015). Extracellular ATP protects against sepsis through macrophage P2X7 purinergic receptors by enhancing intracellular bacterial killing. FASEB J. 29, 3626-3637. doi: 10.1096/fj.15-272450

Dang, K., Bielfeldt, K., Lamb, K., and Gebhart, G. F. (2005). Gastric ulcers evoke hyperexcitability and enhance P2X receptor function in rat gastric sensory neurons. J. Neurophysiol. 93, 3112-3119. doi: 10.1152/jn.01127.2004

Deiteren, A., van der Linden, L., de Wit, A., Ceuleers, H., Buckinx, R., Timmermans, J. P., et al. (2015). P2X3 receptors mediate visceral hypersensitivity during acute chemically-induced colitis and in the post-inflammatory phase via different mechanisms of sensitization. PLoS One 10:e123810. doi: 10.1371/ journal.pone.0123810

Di Virgilio, F., Dal Ben, D., Sarti, A. C., Giuliani, A. L., and Falzoni, S. (2017). The P2X7 receptor in infection and inflammation. Immunity 47, 15-31. doi: 10.1016/j.immuni.2017.06.020

Dranoff, J. A., Kruglov, E. A., Robson, S. C., Braun, N., Zimmermann, H., and Sévigny, J. (2002). The ecto-nucleoside triphosphate diphosphohydrolase 
NTPDase2/CD39L1 is expressed in a novel functional compartment within the liver. Hepatology 36, 1135-1144. doi: 10.1053/jhep.2002.36823

Emmett, D. S., Feranchak, A., Kilic, G., Puljak, L., Miller, B., Dolovcak, S., et al. (2008). Characterization of ionotrophic purinergic receptors in hepatocytes. Hepatology 47, 698-705. doi: 10.1002/hep.22035

Fausther, M., Gonzales, E., and Dranoff, J. A. (2012). Role of purinergic P2X receptors in the control of liver homeostasis. Wiley Interdiscip. Rev. Membr. Transp. Signal. 1, 341-348. doi: 10.1002/wmts.32

Ferrari, D., Pizzirani, C., Adinolfi, E., Lemoli, R. M., Curti, A., Idzko, M., et al. (2006). The P2X7 receptor: a key player in IL-1 processing and release. J. Immunol. 176, 3877-3883. doi: 10.4049/jimmunol.176.7.3877

Fiebich, B. L., Akter, S., and Akundi, R. S. (2014). The two-hit hypothesis for neuroinflammation: role of exogenous ATP in modulating inflammation in the brain. Front. Cell. Neurosci. 8:260. doi: 10.3389/fncel.2014. 00260

Ford, A. P. (2012). In pursuit of P2X3 antagonists: novel therapeutics for chronic pain and afferent sensitization. Purinergic Signal. 8, 3-26. doi: 10.1007/ s11302-011-9271-6

Freire, D., Reyes, R. E., Baghram, A., Davies, D. L., and Asatryan, L. (2019). P2X7 receptor antagonist A804598 inhibits inflammation in brain and liver in C57BL/6J mice exposed to chronic ethanol and high fat diet. J. Neuroimmune Pharmacol. 14, 263-277. doi: 10.1007/s11481-018-9816-3

Galligan, J. J. (2004). Enteric P2X receptors as potential targets for drug treatment of the irritable bowel syndrome. Br. J. Pharmacol. 141, 1294-1302. doi: 10.1038/sj.bjp.0705761

Gebhart, G. F., and Bielefeldt, K. (2016). Physiology of visceral pain. Compr. Physiol. 6, 1609-1633. doi: 10.1002/cphy.c150049

Gentile, D., Natale, M., Lazzerini, P. E., Capecchi, P. L., and Laghi-Pasini, F. (2015). The role of P2X7 receptors in tissue fibrosis: a brief review. Purinergic Signal. 11, 435-440. doi: 10.1007/s11302-015-9466-3

Geschwind, J. F., Hiriart, M., Glennon, M. C., Najafi, H., Corkey, B. E., Matschinsky, F. M., et al. (1989). Selective activation of Ca2+ influx by extracellular ATP in a pancreatic beta-cell line (HIT). Biochim. Biophys. Acta 1012, 107-115. doi: 10.1016/0167-4889(89)90018-9

Gever, J. R., Soto, R., Henningsen, R. A., Martin, R. S., Hackos, D. H., Panicker, S., et al. (2010). AF-353, a novel, potent and orally bioavailable P2X3/P2X2/3 receptor antagonist. Br. J. Pharmacol. 160, 1387-1398. doi: 10.1111/j.14765381.2010.00796.x

Ghalali, A., Martin-Renedo, J., Högberg, J., and Stenius, U. (2017). Atorvastatin decreases $\mathrm{HBx}$-induced phospho-Akt in hepatocytes via $\mathrm{P} 2 \mathrm{X}$ receptors. Mol. Cancer Res. 15, 714-722. doi: 10.1158/1541-7786.MCR-16-0373

Giannuzzo, A., Pedersen, S. F., and Novak, I. (2015). The P2X7 receptor regulates cell survival, migration and invasion of pancreatic ductal adenocarcinoma cells. Mol. Cancer 14:203. doi: 10.1186/s12943-015-0472-4

Giannuzzo, A., Saccomano, M., Napp, J., Ellegaard, M., Alves, F., and Novak, I. (2016). Targeting of the P2X7 receptor in pancreatic cancer and stellate cells. Int. J. Cancer 139, 2540-2552. doi: 10.1002/ijc.30380

Giaroni, C., Knight, G. E., Ruan, H. Z., Glass, R., Bardini, M., Lecchini, S., et al. (2002). P2 receptors in the murine gastrointestinal tract. Neuropharmacology 43, 1313-1323. doi: 10.1016/S0028-3908(02)00294-0

Gonzales, E., Julien, B., Serrière-Lanneau, V., Nicou, A., Doignon, I., Lagoudakis, L., et al. (2010). ATP release after partial hepatectomy regulates liver regeneration in the rat. J. Hepatol. 52, 54-62. doi: 10.1016/j.jhep.2009.10.005

Gonzales, E., Prigent, S., Abou-Lovergne, A., Boucherie, S., Tordjmann, T., Jacquemin, E., et al. (2007). Rat hepatocytes express functional P2X receptors. FEBS Lett. 581, 3260-3266. doi: 10.1016/j.febslet.2007.06.016

Gu, B. J., Zhang, W. Y., Bendall, L. J., Chessell, I. P., Buell, G. N., and Wiley, J. S. (2000). Expression of P2X(7) purinoceptors on human lymphocytes and monocytes: evidence for nonfunctional P2X(7) receptors. Am. J. Physiol. Cell Physiol. 279, C1189-C1197. doi: 10.1152/ajpcell.2000.279.4.C1189

Haanes, K. A., Schwab, A., and Novak, I. (2012). The P2X7 receptor supports both life and death in fibrogenic pancreatic stellate cells. PLoS One 7:e51164. doi: 10.1371/journal.pone.0051164

Habermacher, C., Dunning, K., Chataigneau, T., and Grutter, T. (2016). Molecular structure and function of P2X receptors. Neuropharmacology 104, 18-30. doi: 10.1016/j.neuropharm.2015.07.032

Hattori, M., and Gouaux, E. (2012). Molecular mechanism of ATP binding and ion channel activation in P2X receptors. Nature 485, 207-212. doi: 10.1038 /nature11010
Hofman, P., Cherfils-Vicini, J., Bazin, M., Ilie, M., Juhel, T., Hébuterne, X., et al. (2015). Genetic and pharmacological inactivation of the purinergic P2RX7 receptor dampens inflammation but increases tumor incidence in a mouse model of colitis-associated cancer. Cancer Res. 75, 835-845. doi: 10.1158/0008-5472.CAN-14-1778

Holzer, P. (2011). Acid sensing by visceral afferent neurones. Acta Physiol. 201, 63-75. doi: 10.1111/j.1748-1716.2010.02143.x

Hoque, R., Sohail, M., Malik, A., Sarwar, S., Luo, Y., Shah, A., et al. (2011). TLR9 and the NLRP3 inflammasome link acinar cell death with inflammation in acute pancreatitis. Gastroenterology 141, 358-369. doi: 10.1053/j. gastro.2011.03.041

Hoque, R., Sohail, M. A., Salhanick, S., Malik, A. F., Ghani, A., Robson, S. C., et al. (2012). P2X7 receptor-mediated purinergic signaling promotes liver injury in acetaminophen hepatotoxicity in mice. Am. J. Physiol. Gastrointest. Liver Physiol. 302, G1171-G1179. doi: 10.1152/ajpgi.00352.2011

Hu, J., Qin, X., Song, Z. Y., Yang, P. P., Feng, Y., Sun, Q., et al. (2017). Alphalipoic acid suppresses P2X receptor activities and visceral hypersensitivity to colorectal distention in diabetic rats. Sci. Rep. 7:3928. doi: 10.1038/ s41598-017-17537-1

Huang, C., Yu, W., Cui, H., Wang, Y., Zhang, L., Han, F., et al. (2014). P2X7 blockade attenuates mouse liver fibrosis. Mol. Med. Rep. 9, 57-62. doi: 10.3892/mmr.2013.1807

Iracheta-Vellve, A., Petrasek, J., Satishchandran, A., Gyongyosi, B., Saha, B., Kodys, K., et al. (2015). Inhibition of sterile danger signals, uric acid and ATP, prevents inflammasome activation and protects from alcoholic steatohepatitis in mice. J. Hepatol. 63, 1147-1155. doi: 10.1016/j.jhep.2015.06.013

Jacques-Silva, M. C., Correa-Medina, M., Cabrera, O., Rodriguez-Diaz, R., Makeeva, N., Fachado, A., et al. (2010). ATP-gated P2X3 receptors constitute a positive autocrine signal for insulin release in the human pancreatic beta cell. Proc. Natl. Acad. Sci. U. S. A. 107, 6465-6470. doi: 10.1073/pnas.0908935107

Jarvis, M. F., Burgard, E. C., McGaraughty, S., Honore, P., Lynch, K., Brennan, T. J., et al. (2002). A-317491, a novel potent and selective non-nucleotide antagonist of $\mathrm{P} 2 \mathrm{X} 3$ and $\mathrm{P} 2 \mathrm{X} 2 / 3$ receptors, reduces chronic inflammatory and neuropathic pain in the rat. Proc. Natl. Acad. Sci. U. S. A. 99, 17179-17184. doi: 10.1073/ pnas. 252537299

Jiang, M., Cui, B. W., Wu, Y. L., Zhang, Y., Shang, Y., Liu, J., et al. (2020). P2X7R orchestrates the progression of murine hepatic fibrosis by making a feedback loop from macrophage to hepatic stellate cells. Toxicol. Lett. 333, 22-32. doi: 10.1016/j.toxlet.2020.07.023

Jiang, R., Taly, A., and Grutter, T. (2013). Moving through the gate in ATPactivated P2X receptors. Trends Biochem. Sci. 38, 20-29. doi: 10.1016/j. tibs.2012.10.006

Jiang, R., Taly, A., Lemoine, D., Martz, A., Cunrath, O., and Grutter, T. (2012). Tightening of the ATP-binding sites induces the opening of P2X receptor channels. EMBO J. 31, 2134-2143. doi: 10.1038/emboj.2012.75

Jiang, S., Zhang, Y., Zheng, J. H., Li, X., Yao, Y. L., Wu, Y. L., et al. (2017). Potentiation of hepatic stellate cell activation by extracellular ATP is dependent on P2X7R-mediated NLRP3 inflammasome activation. Pharmacol. Res. 117, 82-93. doi: 10.1016/j.phrs.2016.11.040

Kawamura, H., Aswad, F., Minagawa, M., Govindarajan, S., and Dennert, G. (2006). P2X7 receptors regulate NKT cells in autoimmune hepatitis. J. Immunol. 176, 2152-2160. doi: 10.4049/jimmunol.176.4.2152

Kawate, T. (2017). P2X receptor activation. Adv. Exp. Med. Biol. 1051, 55-69. doi: 10.1007/5584_2017_55

Kentish, S. J., and Page, A. J. (2015). The role of gastrointestinal vagal afferent fibres in obesity. J. Physiol. 593, 775-786. doi: 10.1113/jphysiol.2014.278226

Kestler, C., Neuhuber, W. L., and Raab, M. (2009). Distribution of P2X(3) receptor immunoreactivity in myenteric ganglia of the mouse esophagus. Histochem. Cell Biol. 131, 13-27. doi: 10.1007/s00418-008-0498-4

Kudira, R., Malinka, T., Kohler, A., Dosch, M., de Agüero, M. G., Melin, N., et al. (2016). P2X1-regulated IL-22 secretion by innate lymphoid cells is required for efficient liver regeneration. Hepatology 63, 2004-2017. doi: 10.1002/hep.28492

Künzli, B. M., Berberat, P. O., Giese, T., Csizmadia, E., Kaczmarek, E., Baker, C., et al. (2007). Upregulation of CD39/NTPDases and P2 receptors in human pancreatic disease. Am. J. Physiol. Gastrointest. Liver Physiol. 292, G223-G230. doi: 10.1152/ajpgi.00259.2006

Künzli, B. M., Nuhn, P., Enjyoji, K., Banz, Y., Smith, R. N., Csizmadia, E., et al. (2008). Disordered pancreatic inflammatory responses and inhibition 
of fibrosis in CD39-null mice. Gastroenterology 134, 292-305. doi: 10.1053/j. gastro.2007.10.030

Larrouyet-Sarto, M. L., Tamura, A. S., Alves, V. S., Santana, P. T., Ciarlini-Magalhães, R., Rangel, T. P., et al. (2020). P2X7 receptor deletion attenuates oxidative stress and liver damage in sepsis. Purinergic Signal. 16, 561-572. doi: 10.1007/s11302-020-09746-7

Lashermes, A., Boudieu, L., Barbier, J., Sion, B., Gelot, A., Barnich, N., et al. (2018). Adherent-invasive E. coli enhances colonic hypersensitivity and P2X receptors expression during post-infectious period. Gut Microbes 9, 26-37. doi: 10.1080/19490976.2017.1361091

Le Guilcher, C., Garcin, I., Dellis, O., Cauchois, F., Tebbi, A., Doignon, I., et al. (2018). The P2X4 purinergic receptor regulates hepatic myofibroblast activation during liver fibrogenesis. J. Hepatol. 69, 644-653. doi: 10.1016/j. jhep.2018.05.020

Lecea, B., Martinez, E., Auli, M., Opazo, A., and Clave, P. (2009). Selective stimulation of intrinsic excitatory and inhibitory motor pathways in porcine lower oesophageal sphincter. Neurogastroenterol. Motil. 21:1342-e130. doi: 10.1111/j.1365-2982.2009.01357.x

Lefebvre, R. A., and Burnstock, G. (1990). Effect of adenosine triphosphate and related purines in the rat gastric fundus. Arch. Int. Pharmacodyn. Ther. 303, 199-215.

LeRoy, E. C., Trojanowska, M. I., and Smith, E. A. (1990). Cytokines and human fibrosis. Eur. Cytokine Netw. 1, 215-219.

Li, X., Jin, Q., Zhang, Y., Wu, Y. L., Jin, C. M., Cui, B. W., et al. (2018a). Inhibition of P2X7R-NLRP3 inflammasome activation by Pleurotus citrinopileatus: a possible protective role in alcoholic hepatosteatosis. J. Agric. Food Chem. 66, 13183-13190. doi: 10.1021/acs.jafc.8b05756

Li, X., Zhang, Y., Jin, Q., Xia, K. L., Jiang, M., Cui, B. W., et al. (2018b). Liver kinase B1/AMP-activated protein kinase-mediated regulation by gentiopicroside ameliorates $\mathrm{P} 2 \mathrm{X} 7$ receptor-dependent alcoholic hepatosteatosis. Br. J. Pharmacol. 175, 1451-1470. doi: 10.1111/bph.14145

Lili, W., Yun, L., Tingran, W., Xia, W., and Yanlei, S. (2019). P2RX7 functions as a putative biomarker of gastric cancer and contributes to worse prognosis. Exp. Biol. Med. 244, 734-742. doi: 10.1177/1535370219846492

Lynch, K. J., Touma, E., Niforatos, W., Kage, K. L., Burgard, E. C., van Biesen, T., et al. (1999). Molecular and functional characterization of human P2X(2) receptors. Mol. Pharmacol. 56, 1171-1181. doi: 10.1124/ mol.56.6.1171

Manzoor, S., Akhtar, U., Naseem, S., Khalid, M., Mazhar, M., Parvaiz, F., et al. (2016). Ionotropic purinergic receptors P2X4 and P2X7: proviral or antiviral? An insight into P2X receptor signaling and hepatitis $\mathrm{C}$ virus infection. Viral Immunol. 29, 401-418. doi: 10.1089/vim.2016.0008

Manzoor, S., Idrees, M., Ashraf, J., Mehmood, A., Butt, S., Fatima, K., et al. (2011). Identification of ionotrophic purinergic receptors in Huh-7 cells and their response towards structural proteins of HCV genotype 3a. Virol. J. 8:431. doi: $10.1186 / 1743-422 X-8-431$

Mariathasan, S., and Monack, D. M. (2007). Inflammasome adaptors and sensors: intracellular regulators of infection and inflammation. Nat. Rev. Immunol. 7, 31-40. doi: 10.1038/nri1997

Matharu, M. S., and Hollingsworth, M. (1992). Purinoceptors mediating relaxation and spasm in the rat gastric fundus. Br. J. Pharmacol. 106, 395-403. doi: 10.1111/j.1476-5381.1992.tb14346.x

Mcllwrath, S. L., Davis, B. M., and Bielefeldt, K. (2009). Deletion of P2X3 receptors blunts gastro-oesophageal sensation in mice. Neurogastroenterol. Motil. 21:890-e66. doi: 10.1111/j.1365-2982.2009.01292.x

Mistafa, O., and Stenius, U. (2009). Statins inhibit Akt/PKB signaling via P2X7 receptor in pancreatic cancer cells. Biochem. Pharmacol. 78, 1115-1126. doi: 10.1016/j.bcp.2009.06.016

Miwa, H., Kondo, T., Oshima, T., Fukui, H., Tomita, T., and Watari, J. (2010). Esophageal sensation and esophageal hypersensitivity - overview from bench to bedside. J. Neurogastroenterol. Motil. 16, 353-362. doi: 10.5056/ jnm.2010.16.4.353

Mohammed, A., Qian, L., Janakiram, N. B., Lightfoot, S., Steele, V. E., and Rao, C. V. (2012). Atorvastatin delays progression of pancreatic lesions to carcinoma by regulating PI3/AKT signaling in p48Cre/+ LSL-KrasG12D/+ mice. Int. J. Cancer 131, 1951-1962. doi: 10.1002/ijc.27456

Monif, M., Burnstock, G., and Williams, D. A. (2010). Microglia: proliferation and activation driven by the P2X7 receptor. Int. J. Biochem. Cell Biol. 42, 1753-1756. doi: 10.1016/j.biocel.2010.06.021
Mule, F., Naccari, D., and Serio, R. (2005). Evidence for the presence of P2y and $\mathrm{P} 2 \mathrm{x}$ receptors with different functions in mouse stomach. Eur. J. Pharmacol. 513, 135-140. doi: 10.1016/j.ejphar.2005.01.052

Nakanishi, K., Sakamoto, M., Yamasaki, S., Todo, S., and Hirohashi, S. (2005). Akt phosphorylation is a risk factor for early disease recurrence and poor prognosis in hepatocellular carcinoma. Cancer 103, 307-312. doi: 10.1002/ cncr.20774

Novak, I., Jans, I. M., and Wohlfahrt, L. (2010). Effect of P2X(7) receptor knockout on exocrine secretion of pancreas, salivary glands and lacrimal glands. J. Physiol. 588, 3615-3627. doi: 10.1113/jphysiol.2010.190017

Oberholzer, A., Oberholzer, C., and Moldawer, L. L. (2001). Sepsis syndromes: understanding the role of innate and acquired immunity. Shock 16, 83-96. doi: $10.1097 / 00024382-200116020-00001$

Ohtani, M., Ohura, K., and Oka, T. (2011). Involvement of P2X receptors in the regulation of insulin secretion, proliferation and survival in mouse pancreatic $\beta$-cells. Cell. Physiol. Biochem. 28, 355-366. doi: 10.1159/000331752

Page, A. J., O'Donnell, T. A., and Blackshaw, L. A. (2000). P2X purinoceptorinduced sensitization of ferret vagal mechanoreceptors in oesophageal inflammation. J. Physiol. 523, 403-411. doi: 10.1111/j.1469-7793.2000.00403.x

Qian, F., Xiao, J., Hu, B., Sun, N., Yin, W., and Zhu, J. (2017). High expression of $\mathrm{P} 2 \mathrm{X} 7 \mathrm{R}$ is an independent postoperative indicator of poor prognosis in colorectal cancer. Hum. Pathol. 64, 61-68. doi: 10.1016/j. humpath.2017.03.019

Robert, S., Gicquel, T., Bodin, A., Lagente, V., and Boichot, E. (2016). Characterization of the MMP/TIMP imbalance and collagen production induced by IL- $1 \beta$ or TNF- $\alpha$ release from human hepatic stellate cells. PLoS One 11:e0153118. doi: 10.1371/journal.pone.0153118

Rodrigues, A. M., Bergamaschi, C. T., Fernandes, M. J., Paredes-Gamero, E. J., Buri, M. V., Ferreira, A. T., et al. (2014). P2X(7) receptor in the kidneys of diabetic rats submitted to aerobic training or to $\mathrm{N}$-acetylcysteine supplementation [corrected]. PLoS One 9:e97452. doi: 10.1371/journal. pone. 0097452

Rubartelli, A., and Lotze, M. T. (2007). Inside, outside, upside down: damageassociated molecular-pattern molecules (DAMPs) and redox. Trends Immunol. 28, 429-436. doi: 10.1016/j.it.2007.08.004

Saul, A., Hausmann, R., Kless, A., and Nicke, A. (2013). Heteromeric assembly of P2X subunits. Front. Cell. Neurosci. 7:250. doi: 10.3389/fncel.2013.00250

Savio, L. E. B., de Andrade Mello, P., Figliuolo, V. R., de Avelar Almeida, T. F., Santana, P. T., Oliveira, S. D. S., et al. (2017). CD39 limits P2X7 receptor inflammatory signaling and attenuates sepsis-induced liver injury. J. Hepatol. 67, 716-726. doi: 10.1016/j.jhep.2017.05.021

Shinoda, M., Feng, B., and Gebhart, G. F. (2009). Peripheral and central P2X receptor contributions to colon mechanosensitivity and hypersensitivity in the mouse. Gastroenterology 137, 2096-2104. doi: 10.1053/j.gastro.2009.06.048

Singer, M., Deutschman, C. S., Seymour, C. W., Shankar-Hari, M., Annane, D., Bauer, M., et al. (2016). The third international consensus definitions for sepsis and septic shock (Sepsis-3). JAMA 315, 801-810. doi: 10.1001/ jama.2016.0287

Steer, M. L., Waxman, I., and Freedman, S. (1995). Chronic pancreatitis. N. Engl. J. Med. 332, 1482-1490. doi: 10.1056/NEJM199506013322206

Tung, H. C., Lee, F. Y., Wang, S. S., Tsai, M. H., Lee, J. Y., Huo, T. I., et al. (2015). The beneficial effects of P2X7 antagonism in rats with bile duct ligation-induced cirrhosis. PLoS One 10:e124654. doi: 10.1371/journal. pone. 0124654

Ulmann, L., Hirbec, H., and Rassendren, F. (2010). P2X4 receptors mediate PGE2 release by tissue-resident macrophages and initiate inflammatory pain. EMBO J. 29, 2290-2300. doi: 10.1038/emboj.2010.126

Vieira, F. S., Nanini, H. F., Takiya, C. M., and Coutinho-Silva, R. (2016). P2X7 receptor knockout prevents streptozotocin-induced type 1 diabetes in mice. Mol. Cell. Endocrinol. 419, 148-157. doi: 10.1016/j.mce.2015.10.008

Volonté, C., and Burnstock, G. (2013). P2X3 receptor: a novel 'CASKade' of signaling? J. Neurochem. 126, 1-3. doi: 10.1111/jnc.12282

Wang, J., Haanes, K. A., and Novak, I. (2013). Purinergic regulation of CFTR and $\mathrm{Ca}(2+)$-activated $\mathrm{Cl}(-)$ channels and $\mathrm{K}(+)$ channels in human pancreatic duct epithelium. Am. J. Physiol. Cell Physiol. 304, C673-C684. doi: 10.1152/ ajpcell.00196.2012

Wang, Z. J., and Neuhuber, W. L. (2003). Intraganglionic laminar endings in the rat esophagus contain purinergic $\mathrm{P} 2 \mathrm{X} 2$ and $\mathrm{P} 2 \mathrm{X} 3$ receptor immunoreactivity. Anat. Embryol. 207, 363-371. doi: 10.1007/s00429-003-0351-4 
Wang, J., and Yu, Y. (2016). Insights into the channel gating of P2X receptors from structures, dynamics and small molecules. Acta Pharmacol. Sin. 37, 44-55. doi: 10.1038/aps.2015.127

Wang, S., Zhu, H. Y., Jin, Y., Zhou, Y., Hu, S., Liu, T., et al. (2015). Adrenergic signaling mediates mechanical hyperalgesia through activation of P2X3 receptors in primary sensory neurons of rats with chronic pancreatitis. Am. J. Physiol. Gastrointest. Liver Physiol. 308, G710-G719. doi: 10.1152/ ajpgi.00395.2014

Wirkner, K., Sperlagh, B., and Illes, P. (2007). P2X3 receptor involvement in pain states. Mol. Neurobiol. 36, 165-183. doi: 10.1007/s12035-007-0033-y

Woo, K., Sathe, M., Kresge, C., Esser, V., Ueno, Y., Venter, J., et al. (2010). Adenosine triphosphate release and purinergic (P2) receptor-mediated secretion in small and large mouse cholangiocytes. Hepatology 52, 1819-1828. doi: 10.1002/hep. 23883

Wu, X., Wang, Y., Wang, S., Xu, R., and Lv, X. (2017). Purinergic P2X7 receptor mediates acetaldehyde-induced hepatic stellate cells activation via PKCdependent GSK3 $\beta$ pathway. Int. Immunopharmacol. 43, 164-171. doi: 10.1016/j. intimp.2016.12.017

Wynn, G., Ma, B., Ruan, H. Z., and Burnstock, G. (2004). Purinergic component of mechanosensory transduction is increased in a rat model of colitis. Am. J. Physiol. Gastrointest. Liver Physiol. 287, G647-G657. doi: 10.1152/ ajpgi.00020.2004

Wynn, G., Rong, W., Xiang, Z., and Burnstock, G. (2003). Purinergic mechanisms contribute to mechanosensory transduction in the rat colorectum. Gastroenterology 125, 1398-1409. doi: 10.1016/j.gastro.2003.07.008

Xie, Y., Williams, C. D., McGill, M. R., Lebofsky, M., Ramachandran, A., and Jaeschke, H. (2013). Purinergic receptor antagonist A438079 protects against acetaminophen-induced liver injury by inhibiting p450 isoenzymes, not by inflammasome activation. Toxicol. Sci. 131, 325-335. doi: 10.1093/toxsci/ $\mathrm{kfs} 283$

Xu, G. Y., Shenoy, M., Winston, J. H., Mittal, S., and Pasricha, P. J. (2008). $\mathrm{P} 2 \mathrm{X}$ receptor-mediated visceral hyperalgesia in a rat model of chronic visceral hypersensitivity. Gut 57, 1230-1237. doi: 10.1136/gut.2007.134221

Yiangou, Y., Facer, P., Baecker, P. A., Ford, A. P., Knowles, C. H., Chan, C. L., et al. (2001). ATP-gated ion channel P2X(3) is increased in human inflammatory bowel disease. Neurogastroenterol. Motil. 13, 365-369. doi: 10.1046/j.13652982.2001.00276.x

Zagorodnyuk, V. P., Chen, B. N., Costa, M., and Brookes, S. J. (2003). Mechanotransduction by intraganglionic laminar endings of vagal tension receptors in the Guinea-pig oesophagus. J. Physiol. 553, 575-587. doi: 10.1113/ jphysiol.2003.051862

Zhang, W. J., Hu, C. G., Luo, H. L., and Zhu, Z. M. (2020). Activation of P2×7 receptor promotes the invasion and migration of colon cancer cells via the STAT3 signaling. Front. Cell Dev. Biol. 8:586555. doi: 10.3389/fcell.2020.586555

Zhang, Q., Tao, X., Xia, S., Qu, J., Song, H., Liu, J., et al. (2019). Emodin attenuated severe acute pancreatitis via the P2X ligand-gated ion channel 7/NOD-like receptor protein 3 signaling pathway. Oncol. Rep. 41, 270-278. doi: $10.3892 /$ or.2018.6844

Zoetewij, J. P., van de Water, B., de Bont, H. J., and Nagelkerke, J. F. (1996). The role of a purinergic $\mathrm{P} 2 \mathrm{z}$ receptor in calcium-dependent cell killing of isolated rat hepatocytes by extracellular adenosine triphosphate. Hepatology 23, 858-865. doi: 10.1002/hep.510230429

Conflict of Interest: The authors declare that the research was conducted in the absence of any commercial or financial relationships that could be construed as a potential conflict of interest.

Publisher's Note: All claims expressed in this article are solely those of the authors and do not necessarily represent those of their affiliated organizations, or those of the publisher, the editors and the reviewers. Any product that may be evaluated in this article, or claim that may be made by its manufacturer, is not guaranteed or endorsed by the publisher.

Copyright (C) 2021 An, Yue, Yang, Lou, Shan, Ding, Jin, Hu, Du, Liao, Xie and $\mathrm{Xu}$. This is an open-access article distributed under the terms of the Creative Commons Attribution License (CC BY). The use, distribution or reproduction in other forums is permitted, provided the original author(s) and the copyright owner(s) are credited and that the original publication in this journal is cited, in accordance with accepted academic practice. No use, distribution or reproduction is permitted which does not comply with these terms. 